



\section{Brongerichte maatregelen voor beperking emissies uit bestaande varkensstallen}

André Aarnink ${ }^{1}$, Jos de Groot ${ }^{2}$ en Nico Ogink ${ }^{1}$

1 Wageningen Livestock Research

2 DLV Advies

Dit onderzoek is uitgevoerd door Wageningen Livestock Research, in opdracht van en gefinancierd door het Ministerie van Landbouw, Natuur en Voedselkwaliteit, in het kader van het Beleidsondersteunend onderzoek thema 'Duurzame voedselvoorziening \& -productieketens \& Natuur' (projectnummer BO-43-012.02-050) 
André Aarnink, Jos de Groot en Nico Ogink, 2019. Brongerichte maatregelen voor beperking emissies uit bestaande varkensstallen. Wageningen Livestock Research, Rapport 1205.

Samenvatting NL. De coalitie Vitalisering varkenshouderij heeft met betrokken provincies en LNV het initiatief genomen voor een brongerichte verduurzaming van varkensstallen. Doelstelling is dat schadelijke emissies uit varkensstallen zoveel mogelijk brongericht en integraal worden voorkomen. In dit rapport wordt inzicht gegeven in de aangrijpingspunten die er zijn en in de maatregelen die genomen kunnen worden om emissies integraal bij de bron te reduceren in bestaande stallen voor de verschillende categorieën varkens. Het perspectief van mogelijke maatregelen, de impact op de emissies en de mogelijkheid om maatregelen te combineren, eventueel met nageschakelde technieken, worden daarbij aangegeven. Daarnaast wordt inzicht gegeven in lopende initiatieven op dit terrein in Nederland en in het buitenland.

Summary UK. The coalition Vitalization of pig farming has taken the initiative, with the provinces and LNV, for a source-oriented sustainability improvement of pig houses. The objective is that harmful emissions from pig houses are prevented as far as possible directly from the source and integral. This report provides insight into the points of application and the measures that can be taken to reduce emissions integrally at the source in existing housing for the different categories of pigs. The perspective of possible measures, the impact on emissions and the possibility of combining measures, possibly with end-of-pipe solutions, are indicated. In addition, insight is provided into current initiatives in this field in the Netherlands and abroad.

Dit rapport is gratis te downloaden op https://doi.org/10.18174/502631 of op www.wur.nl/livestock-research (onder Wageningen Livestock Research publicaties).

(C) 2019 Wageningen Livestock Research

Postbus 338, 6700 AH Wageningen, T 03174839 53, E info.livestockresearch@wur.nl, www.wur.nl/livestock-research. Wageningen Livestock Research is onderdeel van Wageningen University \& Research.

Wageningen Livestock Research aanvaardt geen aansprakelijkheid voor eventuele schade voortvloeiend uit het gebruik van de resultaten van dit onderzoek of de toepassing van de adviezen.

Alle rechten voorbehouden. Niets uit deze uitgave mag worden vermenigvuldigd en/of openbaar gemaakt worden door middel van druk, fotokopie, microfilm of op welke wijze dan ook zonder voorafgaande toestemming van de uitgever of auteur.

Wageningen Livestock Research is NEN-EN-ISO 9001:2015 gecertificeerd.

Op al onze onderzoeksopdrachten zijn de Algemene Voorwaarden van de Animal Sciences Group van toepassing. Deze zijn gedeponeerd bij de Arrondissementsrechtbank Zwolle. 


\section{Inhoud}

3.1 Groslijst van (integrale) brongerichte maatregelen $\quad 7$

3.2 Kansrijke brongerichte maatregelen voor bestaande stallen 10

3.3 Combinaties van brongerichte maatregelen 14

3.4 Combinaties van brongerichte maatregelen en nageschakelde technieken $\quad 17$

$\begin{array}{lll}3.5 & \text { Initiatieven in Nederland en het buitenland } & 17\end{array}$

4

$\begin{array}{ll}\text { Discussie } & 20\end{array}$

5

$\begin{array}{ll}\text { Samenvattende conclusies } & \mathbf{2 4}\end{array}$

Bijlage 1 



\section{$1 \quad$ Inleiding}

In het Regeerakkoord heeft het kabinet $€ 200$ miljoen gereserveerd voor een warme sanering van de varkenshouderij. In het Hoofdlijnenakkoord van 7 juli 2018 is afgesproken dat de Coalitie vitalisering varkenshouderij in overleg met LNV, de betrokken provincies en VNG het initiatief neemt voor een meerjarig innovatie- en versnellingsprogramma voor een brongerichte verduurzaming van varkensstallen. Doelstelling is dat schadelijke emissies uit varkensstallen zoveel mogelijk brongericht worden voorkomen. Hiermee wordt niet alleen de luchtkwaliteit in de omgeving van het varkensbedrijf verbeterd, maar ook de luchtkwaliteit in de stal. Dit vermindert de gezondheids-risico's voor zowel de leefomgeving als voor de varkenshouder en zijn dieren.

De provincie Noord-Brabant, waar circa 50\% van de Nederlandse varkens worden gehouden, heeft in haar transitiebeleid verduurzaming veehouderij bepaald dat alle bestaande varkensstallen vanaf 2022 moeten voldoen aan aangescherpte ammoniakeisen en dat de voorkeur daarbij uitgaat naar brongerichte maatregelen. Daartoe dienen uiterlijk 1-1-2020 ontvankelijke vergunningsaanvragen te worden ingediend. Dit vereist een versnelling van de ontwikkeling van effectieve maatregelen voor bestaande stallen.

De coalitie Vitalisering varkenshouderij heeft met betrokken provincies en LNV het initiatief genomen voor een brongerichte verduurzaming van varkensstallen. Doelstelling is dat schadelijke emissies uit varkensstallen zoveel mogelijk brongericht en integraal worden voorkomen. Voor de uitwerking van het programma is inzicht nodig in aangrijpingspunten en maatregelen voor brongerichte emissiearme maatregelen voor de verschillende categorieën varkens in bestaande stallen. Het gaat hierbij om het perspectief van mogelijke maatregelen, impact op emissie, en de mogelijkheid maatregelen te combineren/stapelen, of te combineren met nageschakelde technieken. Daarnaast is inzicht gewenst in lopende initiatieven op dit terrein in Nederland en buitenland, en het ontwikkelingsstadium waarin deze zich bevinden. Ten slotte ligt er de vraag hoe deze initiatieven verder te brengen. De kennisbehoefte bestaat uit het verkrijgen van bovengenoemde inzichten in de vorm van een samenvattend document met tabellen om daarmee de uitvoering van het innovatie- en versnellingsprogramma te ondersteunen.

In hoofdstuk 2 worden de vragen weergegeven die gesteld zijn door de coalitie Vitalisering varkenshouderij en deze worden in hoofdstuk 3 beantwoord. In hoofdstuk 4 wordt een discussie gevoerd over de maatregelen die het meeste perspectief bieden voor een integrale reductie van emissies bij de bron en in welke stallen deze toepasbaar zijn. In hoofdstuk 5 tenslotte worden de samenvattende conclusies gegeven. 


\section{Te beantwoorden vragen}

Vragen die gesteld zijn door de coalitie Vitalisering varkenshouderij en die in dit rapport worden beantwoord:

1. Wat zijn aangrijpingspunten en mogelijke maatregelen voor een integrale brongerichte aanpak van emissies (geur, ammoniak, methaan, fijnstof en endotoxinen) in bestaande varkensstallen die leiden tot een sterke vermindering van emissies naar de leefomgeving en een sterke verbetering van het stalklimaat? Splits dit uit voor de volgende vier diercategorieën: dragende zeugen, kraamzeugen, gespeende biggen, vleesvarkens.

2. Welke brongerichte maatregelen zijn het meest kansrijk voor bestaande stallen, uitgesplitst naar de vier diercategorieën?

3. Wat zijn de potentiële emissiereducties die behaald kunnen worden?

4. Welke brongerichte maatregelen kunnen in bestaande varkensstallen gecombineerd/gestapeld worden en wat zijn de potentiële emissiereducties, uitgesplitst naar de vier diercategorieën?

5. Welke nageschakelde technieken kunnen gecombineerd worden met brongerichte maatregelen in bestaande varkensstallen en wat zijn de potentiële emissiereducties, uitgesplitst naar de vier diercategorieën?

6. Welke initiatieven in Nederland en het buitenland zijn er die toepasbaar zijn in bestaande stallen, uitgesplitst naar de vier diercategorieën? Maak daarbij gebruik van het overzicht Stalsystemen in de conceptfase van provincie Noord-Brabant.

7. In welke fase van de innovatiecyclus bevinden deze initiatieven zich? i. Ideevorming, ii. Ontwikkeling prototype, iii. Implementatie prototype (testen, valideren, onderzoek, doormeten), iv. Marktintroductie/uitrol (praktijkrijp, wettelijk erkend (Rav, Rgv)).

8. Wat is er nodig om deze initiatieven verder te brengen? (Onderzoek, testen/valideren op praktijkbedrijven, metingen, wettelijke erkenning, stimuleren marktintroductie/demonstratie, uitrol). 


\section{Antwoord op de vragen}

\subsection{Groslijst van (integrale) brongerichte maatregelen}

In deze paragraaf zal ingegaan worden op vraag 1 :

1. 'Wat zijn aangrijpingspunten en mogelijke maatregelen voor een integrale brongerichte aanpak van emissies (geur, ammoniak, methaan, fijnstof en endotoxinen) in bestaande varkensstallen die leiden tot een sterke vermindering van emissies naar de leefomgeving en een sterke verbetering van het stalklimaat? Splits dit uit voor de volgende vier diercategorieën: dragende zeugen, kraamzeugen, gespeende biggen, vleesvarkens.'

De grens tussen wat mogelijk is in bestaande stallen of alleen in nieuwe stallen is niet absoluut. Daarom zullen we in deze paragraaf in eerste instantie een groslijst geven van aangrijpingspunten en mogelijke maatregelen voor een integrale brongerichte aanpak van emissies (geur, ammoniak, methaan, fijnstof en endotoxinen) in bestaande en nieuw te bouwen stallen.

Opmerkingen vooraf:

- In overleg met de opdrachtgever is de volgende omschrijving gehanteerd voor brongerichte maatregelen: 'In het innovatieprogramma Zorg voor de Leefomgeving varkenshouderij ligt de focus primair op het ontwikkelen, onderzoeken en testen van brongerichte maatregelen waarmee schadelijke emissies zoveel mogelijk worden voorkomen. Het kan daarbij gaan om technische maatregelen (bijv. regelmatige verwijdering van varkensmest uit de stal in combinatie met scheiding in een dunne en dikke fractie) en managementmaatregelen (bijv. veevoer, additieven in mest en veevoer). Voor de gewenste meervoudige integrale emissiereducties naar de leefomgeving (o.a. fijnstof/endotoxinen) en de gewenste kwaliteit van de lucht in de stal kunnen, zoveel mogelijk in combinatie met bronmaatregelen, nageschakelde technieken zoals luchtbehandeling in de stal (bijv. voor fijn stof) of (deels)luchtafzuiging onder de roosters in combinatie met een luchtwasser worden doorontwikkeld en getest. Laatstgenoemde techniek is met name bedoeld voor reductie van emissie en verbetering van lucht in de stal bij dié bestaande stallen waar emissie aan de bron bouwkundig of praktisch niet haalbaar is. Op deze manier wordt voorkomen dat de aandacht in het innovatieprogramma eenzijdig wordt gericht op luchtbehandelingstechnieken en verbeterde luchtwassers.'

- Ammoniak, geur en broeikasgassen (vooral methaan) komen voor een belangrijk deel vrij uit mengmest in de mestput. Fijnstof daarentegen komt vooral vrij via opgedroogde feces op de vloer en huidschilfers van de varkens. Fijnstofreductie bij de bron zal daarom vrijwel altijd aanvullende maatregelen vergen t.o.v. de maatregelen gericht op de emissies uit mengmest.

- We beperken ons in dit document tot de emissies in de stal. Natuurlijk moet voorkomen worden dat emissies die in stal worden gereduceerd buiten de stal alsnog emitteren. Voor ammoniak en geur geldt dat afdekken van buitenopslagen en emissiearm aanwenden de emissies verder in de keten belangrijk kunnen beperken. Voor methaan geldt dit in iets mindere mate. Langdurige opslag in een buitenopslag kan significante methaanemissies geven, alhoewel daar nog niet veel over bekend is. Wel is het zo dat de gemiddelde temperatuur van de mest in een buitenopslag beduidend lager is dan bij opslag in de stal. Onderzoek is nodig om dit verschil in methaanemissie tussen binnen- en buitenopslag vast te stellen. Het beste is om de mest snel verder te brengen in de keten (aanwenden of verwerken).

Groslijst integrale brongerichte maatregelen (eventueel via combinatie met andere maatregelen):

- Mest snel en volledig uit de stal

- Mestschuiven (voorkomen moet worden dat urease-activiteit zich ontwikkelt door toepassing van coatings, rubber, biocides (bacteriedodende middelen) of ureaseremmers

- Mestbanden (gladde mestbanden, zoals poly-propyleen, poly-ethyleen; geen pvc)

- Mestpannen (i.c.m. andere maatregelen, zoals verkleining emitterend oppervlak en koeling) 
- Foliepannen (dit zijn pannen gemaakt van folie; deze kunnen toegepast worden in kanalen met een rioleringssysteem; de folie wordt daarbij schuin gespannen (kelder moet voldoende diepte hebben) tussen de rioleringspijp en de roostervloer; mest wordt continu afgevoerd.)

- Mestopvang in en spoelen met vloeistof (i.c.m. scheiding van mest in dun en dik buiten de stal):

- Ammoniak-arme vloeistof (b.v. via beluchting; water)

- Aangezuurde vloeistof

- Formaldehyde behandelde mestvloeistof

- Dagelijks spoelen met verse mest (i.c.m. andere maatregelen zoals verkleining emitterend oppervlak en koeling)

- Aanzuren van mest (Deens systeem, waarbij de mest wordt aangezuurd buiten de stal en voor een deel weer wordt terug gezet in de mestkelder; $(\mathrm{pH}<6$; emissies van ammoniak en methaan worden gereduceerd; heeft geen effect op geuremissie (Kai et al., 2008))

Deze maatregelen zullen, tenzij anders aangegeven, zowel de emissies van ammoniak, geur als methaan beperken. Bij methaan moet voorkomen worden dat het tijdens de opslag van de mest buiten de stal alsnog emitteert. De buitentemperatuur is gemiddeld wel beduidend lager dan de staltemperatuur, waardoor methaanvorming in de buiten-mestopslag geringer zal zijn.

- Verkleining emitterend oppervlak

Water- en mestkanaal

Schuine wanden

Verkleining rooster- en kelderoppervlakte

Deze maatregelen zullen vooral de emissie van ammoniak beperken.

- Koelen van de mest en gebruik onttrokken energie

- Alleen aan oppervlakte (vooral effect op de ammoniakemissie)

- Volledige mest (effect op ammoniak, geur en methaan)

- Oppervlaktebehandeling van de mest

- Olielaag (vermindering ammoniakemissie; naar verwachting zal tevens de geuremissie worden gereduceerd, de mate waarin is echter onduidelijk; er wordt geen effect op de methaanemissie verwacht)

- Oppervlaktebeluchting mest (nog in een ideestadium; nog geen systeem voorhanden; verwachte reductie voor ammoniak, geur en methaan)

- $\quad$ Beluchting mest van onderuit de mestkelder

- Een variant van dit systeem is bij melkvee onderzocht (bellenbeluchting); vooral effect op ammoniakemissie, maar resultaten waren uiteindelijk minder positief dan in eerste instantie gemeten; bij ruime beluchting mogen ook effecten op geur- en methaanemissies worden verwacht.

- Voermaatregelen

- Lage N-gehalten; optimaal aminozurenpatroon (effect op ammoniak en geur)

- Verzurende voeders (vooral effect op ammoniakemissie)

- Zeer goed verteerbare voeders (astronautenvoer) (effect op geur en methaan)

- Eigen voer maken (bijproducten) (effecten sterk afhankelijk van gebruikte bijproducten; emissies kunnen zowel gereduceerd worden als toenemen.)

- $\quad$ Opvang mest in water i.c.m. mestscheiding

- Mest en urine worden opgevangen in water. Deze (dunne) mest wordt regelmatig afgevoerd en buiten de stal gescheiden. De dunne fractie wordt op eigen grond aangewend of gezuiverd en hergebruikt. Het verschil van deze maatregel met de snelle verwijdering van mest uit de stal is dat de mest bij dit systeem langer in de stal blijft (b.v. een maand). (Verwachte reducties van ammoniak, geur en methaan)

- Varkenstoilet

- Varkens trainen (b.v. via beloning) om op het toilet te mesten 
Verwachte reducties van ammoniak, geur en methaan; afhankelijk van de precieze uitvoering kan stof ook gereduceerd worden (wanneer de dieren vrijwel niet meer in aanraking komen met de mest)

- Schone vloeren

- Coaten van vloeren en wanden (zonder dat de beloopbaarheid hierdoor problematisch wordt)

- Goed doorlatende roosters

- Goede klimatisering en hokinrichting

- Sproeien van de roosters

Verwachte reducties van ammoniak, geur en fijnstof.

- $\quad$ Strostal voor drachtige zeugen (Rondloopstal)

- Lagere emissies van geur en methaan. Effect op de ammoniakemissie hangt sterk af van de uitvoering. Effect op fijnstof is onduidelijk. Grotere kans op emissie van lachgas.

- $\quad$ Specifieke stofreductiemethoden

- Olienippel

- Oliefilmsysteem met drukleiding

- (Toevoeg)middelen

- Toevoegmiddelen aan voer, mest of sprayen in de lucht. Er zijn alleen effecten te verwachten als er een duidelijk en gevalideerd werkingsmechanisme aan ten grondslag ligt.

Onderstaande maatregelen zijn een tussenvorm van brongericht en end of pipe. Deze systemen voorkomen niet dat vervuilende componenten emitteren uit de bron, maar zorgen er wel voor dat de luchtkwaliteit op dier- en mensniveau verbetert.

- $\quad$ Onderafzuiging van de stallucht (onder de roostervloer) i.c.m. een luchtwasser

\author{
- Geheel \\ - Gedeeltelijk( i.c.m. ventilatie van de stalruimte)
}

Bij gedeeltelijke afzuiging onder de roostervloer zijn er twee opties: 1) alleen deze deelstroom reinigen met een luchtwasser; 2) alle ventilatielucht reinigen met een luchtwasser. Deze maatregelen kunnen vooral de emissies van ammoniak en geur beperken. Bij volledige reiniging wordt ook fijnstof belangrijk gereduceerd; dit gebeurt in mindere mate bij alleen reiniging van de deelstroom. Deze maatregel heeft geen effect op de methaanemissie. De luchtkwaliteit in de stal kan door deze maatregel sterk worden verbeterd (in mindere mate voor stof). Deze maatregel vergt echter nog wel enig onderzoek. In Denemarken zijn zeer positieve resultaten gevonden bij toepassing van dit systeem in combinatie met plafondventilatie. In Nederland waren de resultaten minder gunstig bij voergangventilatie. Er moet een goede luchtstroming in de stal worden gecreëerd zodat de vuile kelderlucht zoveel mogelijk met de luchtstroom onder de roosters wordt afgevoerd.

- Gedeeltelijke recirculatie van lucht

- Lucht uit de afdelingen wordt na reiniging en conditionering voor een deel weer terug gebracht in de stal (reductie van ammoniak-, geur- en fijnstofemissie; geen reductie van methaan); op deze manier kan de minimum ventilatie worden verhoogd zonder extra verwarmingskosten en wordt er minder lucht uitgewisseld met de omgeving, waardoor de emissies ook worden verlaagd (behalve voor methaan).

- $\quad$ Luchtreiniging in de stal

- Koude plasmatechnologie (nog in ontwikkeling; energieverbruik moet worden teruggebracht; verwachte reductie van ammoniak, geur, methaan en fijnstof)

- Hogere minimum ventilatie i.c.m. conditionering inkomende lucht

- De emissies van ammoniak, geur en fijnstof zullen enigszins worden beperkt door minder bevuiling; stalklimaat kan hiermee sterk worden verbeterd. 
- $\quad$ Specifieke stofreductiemethoden

- Negatieve ionisatie

- Interne luchtcirculatie met stoffiltratie (alleen stofreductie)

In bijlage 1 wordt van bovenstaande groslijst aangegeven wat de verwachte effecten zijn op de emissies en of ze al dan niet in bestaande stallen kunnen worden toegepast en voor welke categorieën varkens ze geschikt zijn. De emissiereducties zijn ingeschat voor de situatie met vleesvarkens, maar deze reducties kunnen i.h.a. redelijk geëxtrapoleerd worden naar de andere diercategorieën.

De aangegeven emissiereducties zijn indicatief, afgerond op 5\%, in het algemeen nog niet gemeten en gebaseerd op een optimale werking van het systeem. Voor ammoniak zijn de schattingen vooral gebaseerd op modelberekeningen en voor geur, methaan en fijnstof vooral op expertkennis.

\subsection{Kansrijke brongerichte maatregelen voor bestaande stallen}

In deze paragraaf zal ingegaan worden op vragen 2 en 3 :

2. 'Welke brongerichte maatregelen zijn het meest kansrijk voor bestaande stallen, uitgesplitst naar de vier diercategorieën?'

3. 'Wat zijn de potentiële emissiereducties die behaald kunnen worden?'

In tabel 1 is een overzicht gegeven van de meest kansrijke brongerichte maatregelen voor bestaande stallen. In de tabel zijn indicatieve schattingen gemaakt van de reducties van ammoniak, geur, methaan en fijnstof. Hierbij is het nieuwe systeem vergeleken met een systeem dat valt onder 'Overige huisvestingsystemen' in de Rav-lijst. De methaanreductie is daarbij ingeschat ten opzichte van een systeem met langdurige opslag van mest in de stal. De reducties zijn ingeschat voor vleesvarkens, maar deze zijn redelijk goed te extrapoleren naar de andere varkenscategorieën. In de tabel is tevens aangegeven wat het verwachte effect is op de luchtkwaliteit in de stal en welke mate van renovatie nodig is voor implementatie van de maatregel in bestaande stallen. Daarnaast is aangegeven voor welke varkenscategorieën de maatregel geschikt is. Opgemerkt moet worden dat de mate van renovatie nog weinig zegt over de totale jaarkosten van de systemen. Daarvoor is een uitgebreide economische analyse nodig.

Toelichting op tabel:

- Brongerichte emissiemaatregelen in de mestput zijn vaak gemakkelijker toe te passen bij biggenhokken en kraamhokken, vooral vanwege de vaak lichtere vorm van hokinrichting en roostervloeren. Bij vleesvarkens en drachtige zeugen is dit vaak lastiger vanwege de vaak zware hokinrichting, zoals betonroosters en betonnen hokinrichting. Daarnaast zijn betonnen roostervloeren vaak vast gestort aan de dichte vloer. Dit betekent in dat geval dat de gehele vloer met hokinrichting gesloopt moet worden met relatief zware machines om het materiaal uit de stal te halen of te verplaatsen. Dit zal via openingen in dak of muur moeten gebeuren. Veranderingen zijn bij deze diercategorieën dus vaak zeer ingrijpend.

- De tussenvormen van de brongerichte maatregelen zijn opgenomen aan het eind van de tabel. Bij een tussenvorm wordt de luchtkwaliteit op dierniveau (en mensniveau) wel verbeterd, maar wordt niet voorkomen dat vervuilende componenten emitteren uit de bron.

- Voor de combi-wassers is uitgegaan van het aangepaste geurrendement van 45\%. Er loopt op dit moment onderzoek naar mogelijkheden om dit rendement te verbeteren. De verwachting is dat met een juiste uitvoering van combi-wassers een beduidend hoger geurrendement verkregen kan worden. 


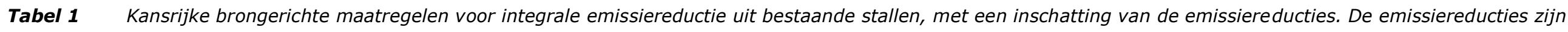
ingeschat voor vleesvarkens, maar redelijk goed te extrapoleren naar de andere categorieën varkens. Tevens is aangegeven wat het verwachte effect is op de luchtkwaliteit in de stal, welke mate van renovatie benodigd is voor implementatie in bestaande stallen en voor welke varkenscategorieën de maatregel geschikt is. Opmerking: de aangegeven emissiereducties zijn indicatief, afgerond op 5\%, in het algemeen nog niet gemeten en gebaseerd op een optimale werking van het systeem. Voor ammoniak zijn de schattingen vooral gebaseerd op modelberekeningen en voor geur, methaan en fijnstof vooral op expertkennis.

\begin{tabular}{|c|c|c|c|c|c|c|c|c|}
\hline Brongerichte maatregel & $\begin{array}{l}\text { NH3-red. } \\
(\%)\end{array}$ & $\begin{array}{l}\text { Geurred. } \\
(\%)\end{array}$ & $\begin{array}{l}\text { Methaanred. } \\
(\%)\end{array}$ & $\begin{array}{l}\text { Fijnstofred. } \\
(\%)\end{array}$ & $\begin{array}{l}\text { Luchtkwaliteit } \\
\text { in stal }{ }^{1}\end{array}$ & $\begin{array}{l}\text { Mate van } \\
\text { renovatie } \\
\text { stal }^{2}\end{array}$ & $\begin{array}{l}\text { Categorie- } \\
e \mathrm{e}^{3}\end{array}$ & Voetnoot \\
\hline
\end{tabular}

\begin{tabular}{|c|c|c|c|c|c|c|c|c|}
\hline \multicolumn{9}{|l|}{ Mest snel en volledig uit de stal } \\
\hline $\begin{array}{l}\text { Mestschuif over gecoate vlakke/hellende vloer met biocide / } \\
\text { vloer bekleed met rubber/polyethyleen/polypropyleen }\end{array}$ & $60 \%$ & $60 \%$ & $90 \%$ & $0 \%$ & ++ & Groot & Alle & 4 \\
\hline $\begin{array}{l}\text { Mestpannen met schuine wanden ( } 50 \% \text { reductie emit. opp.); } \\
\text { wekelijks mest verwijderen }\end{array}$ & $40 \%$ & $40 \%$ & $80 \%$ & $0 \%$ & + & Groot & Alle & \\
\hline $\begin{array}{l}\text { Foliepannen (continue mestverwijdering; } 1 \times \text { /dag sproeien met } \\
\text { water en biocide) }\end{array}$ & $50 \%$ & $60 \%$ & $90 \%$ & $0 \%$ & ++ & Groot & Alle & \\
\hline $\begin{array}{l}\text { Opvang en spoelen met ammoniakvrije en geurarme vloeistof } \\
\text { (water of dunne fractie na behandeling) }\end{array}$ & $65 \%$ & $60 \%$ & $90 \%$ & $0 \%$ & ++ & Middel & Alle & 5 \\
\hline Opvang en spoelen met zure vloeistof & $65 \%$ & $20 \%$ & $90 \%$ & $0 \%$ & ++ & Middel & Alle & 5 \\
\hline $\begin{array}{l}\text { Opvang en spoelen met formaldehyde behandelde } \\
\text { mestvloeistof }\end{array}$ & $65 \%$ & $20 \%$ & $90 \%$ & $0 \%$ & ++ & Middel & Alle & 5 \\
\hline $\begin{array}{l}\text { Dagontmesting door spoelen met verse mest; verkleining } \\
\text { emitterend mestoppervlak }(67 \%) \text {; koeling }(<15 \circ \mathrm{C})\end{array}$ & $60 \%$ & $50 \%$ & $90 \%$ & $0 \%$ & ++ & Groot & Alle & \\
\hline Aanzuren van mest ( $\mathrm{pH}<6$; Deens systeem) & $70 \%$ & $0 \%$ & $90 \%$ & $0 \%$ & ++ & Middel & Alle & 6 \\
\hline \multicolumn{9}{|l|}{ Verkleining emitterend oppervlak } \\
\hline Water- en mestkanaal & $35 \%$ & $20 \%$ & $20 \%$ & $0 \%$ & + & Klein & Alle & 6,7 \\
\hline $\begin{array}{l}\text { Schuine wanden in mestkanaal ( } 67 \% \text { verkleining emit. opp. } \\
\text { mestkanaal) eventueel i.c.m. waterkanaal }\end{array}$ & $50 \%$ & $25 \%$ & $20 \%$ & $0 \%$ & + & Middel & Alle & 6 \\
\hline \multicolumn{9}{|l|}{ Koelen van mest } \\
\hline Alleen oppervlakte mest & $56 \%$ & $20 \%$ & $20 \%$ & $0 \%$ & + & Middel & Alle & 6 \\
\hline Volledige mest & $55 \%$ & $30 \%$ & $50 \%$ & $0 \%$ & + & Middel & Alle & 6 \\
\hline
\end{tabular}




\begin{tabular}{|c|c|c|c|c|c|c|c|c|}
\hline Brongerichte maatregel & $\begin{array}{l}\text { NH3-red. } \\
(\%)\end{array}$ & $\begin{array}{l}\text { Geurred. } \\
(\%)\end{array}$ & $\begin{array}{l}\text { Methaanred. } \\
(\%)\end{array}$ & $\begin{array}{l}\text { Fijnstofred. } \\
(\%)\end{array}$ & $\begin{array}{l}\text { Luchtkwaliteit } \\
\text { in stal }{ }^{1}\end{array}$ & $\begin{array}{l}\text { Mate van } \\
\text { renovatie } \\
\text { stal }^{2}\end{array}$ & $\begin{array}{l}\text { Categorie- } \\
\text { ën }^{3}\end{array}$ & Voetnoot \\
\hline \multicolumn{9}{|l|}{ Beluchting mest } \\
\hline Bellenbeluchting mest & $40 \%$ & $20 \%$ & $20 \%$ & $0 \%$ & + & Klein & Alle & 6 \\
\hline \multicolumn{9}{|l|}{ Voermaatregelen } \\
\hline Laag eiwitgehalte; optimaal aminozurenpatroon & $25 \%$ & $30 \%$ & $0 \%$ & $0 \%$ & + & Geen & Alle & 8 \\
\hline Verzurende voeders; benzoëzuur & $15 \%$ & $0 \%$ & $0 \%$ & $0 \%$ & + & Geen & Alle & 9 \\
\hline \multicolumn{9}{|l|}{ Verdunnen van mest } \\
\hline $\begin{array}{l}\text { Opvang mest in water i.c.m. mestscheiding (dunne fractie } \\
\text { eigen grond of zuiveren en hergebruiken) }\end{array}$ & $55 \%$ & $20 \%$ & $30 \%$ & $0 \%$ & ++ & Middel & Alle & 6 \\
\hline \multicolumn{9}{|l|}{ Schone vloeren } \\
\hline Coaten vloeren en wanden & $5 \%$ & $5 \%$ & $0 \%$ & $5 \%$ & + & Klein & Alle & \\
\hline $\begin{array}{l}\text { Goed doorlatende metalen roosters (driekant, met/zonder } \\
\text { mestspleet) }\end{array}$ & $20 \%$ & $20 \%$ & $0 \%$ & $20 \%$ & + & Middel & Alle & 6,10 \\
\hline Goede klimatisering en hokinrichting & $20 \%$ & $20 \%$ & $0 \%$ & $20 \%$ & + & Middel & Alle & \\
\hline Watersproeien op roostervloer tijdens activiteitperioden & $20 \%$ & $10 \%$ & $0 \%$ & $35 \%$ & ++ & Middel & $V, B, D$ & \\
\hline \multicolumn{9}{|l|}{ Specifieke stofreductie methoden } \\
\hline Olienippel & $0 \%$ & $0 \%$ & $0 \%$ & $65 \%$ & ++ & Klein & $V, B, D$ & \\
\hline
\end{tabular}

Tussenvormen brongerichte maatregelen

Onderafzuiging van de stallucht onder de roostervloer

i.c.m. een luchtwasser

Gedeeltelijk onder de roostervloer (min. ventilatie); wassen; 95\% chemische wasser

Gedeeltelijk onder de roostervloer (min. ventilatie); volledig wassen; $70 \%$ biologische wasser

Gedeeltelijk onder de roostervloer (min. ventilatie); volledig

$95 \%$

$30 \%$

$0 \%$

$70 \%$

$45 \%$

$0 \%$

$85 \%$

$45 \%$

$0 \%$

$65 \%$

$20 \%$

$0 \%$

$85 \%$ gecombineerde wasser

Gedeeltelijk onder de roostervloer (min. ventilatie);

gedeeltelijk wassen; $95 \%$ chemische wasser

12 | Wageningen Livestock Research Rapport 1205 


\begin{tabular}{|c|c|c|c|c|c|c|c|c|}
\hline Brongerichte maatregel & $\begin{array}{l}\text { NH3-red. } \\
(\%)\end{array}$ & $\begin{array}{l}\text { Geurred. } \\
(\%)\end{array}$ & $\begin{array}{l}\text { Methaanred. } \\
(\%)\end{array}$ & $\begin{array}{l}\text { Fijnstofred. } \\
(\%)\end{array}$ & $\begin{array}{l}\text { Luchtkwaliteit } \\
\text { in stal }{ }^{1}\end{array}$ & $\begin{array}{l}\text { Mate van } \\
\text { renovatie } \\
\text { stal }^{2}\end{array}$ & $\begin{array}{l}\text { Categorie- } \\
\text { ën }^{3}\end{array}$ & Voetnoot \\
\hline $\begin{array}{l}\text { Gedeeltelijk onder de roostervloer (min. ventilatie); } \\
\text { gedeeltelijk wassen; } 70 \% \text { biologische wasser }\end{array}$ & $50 \%$ & $30 \%$ & $0 \%$ & $40 \%$ & ++ & Middel & Alle & 6 \\
\hline $\begin{array}{l}\text { Gedeeltelijk onder de roostervloer (min. ventilatie); } \\
\text { gedeeltelijk wassen; } 85 \% \text { gecombineerde wasser }\end{array}$ & $60 \%$ & $30 \%$ & $0 \%$ & $40 \%$ & ++ & Middel & Alle & 6 \\
\hline
\end{tabular}

\section{Gedeeltelijke recirculatie van lucht i.c.m. een}

\section{luchtwasser}

Gedeeltelijke recirculatie van lucht met combiwasser 85\%

Hogere minimumventilatie i.c.m. een luchtwasse

Conditionering inkomende lucht met warmtewisselaar en

$90 \%$

$50 \%$

$95 \%$

$30 \%$

$0 \%$

$0 \%$

$0 \%$

$85 \%$

verhoging minimum ventilatie, i.c.m. chemische luchtwasser

$95 \%$

\section{Specifieke stofreductie methoden}

Negatieve luchtionisatie

$0 \% \quad 0 \%$

$0 \%$

$\begin{array}{ll}++ \\ \% & +++\end{array}$

Groot

$\begin{array}{llc}\text { Groot } & \text { Alle } & 11 \\ & & \\ \text { Middel } & \text { Alle } & 12\end{array}$

1) 0 = geen effect; +/- = effect onbekend; + = gematigd positief; ++ = positief; +++ = zeer positief

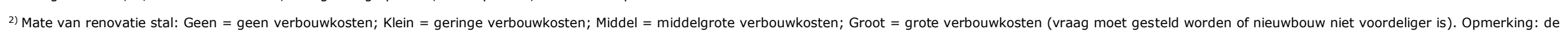
werkelijke renovatiekosten hangen sterk samen met de bedrijfssituatie en de totale kosten hangen daarnaast af van de aanvullende technieken buiten de stal.

3) Bij welke categorieën varkens kan de maatregel worden toegepast; alle = bij alle categorieën; $V=$ bij vleesvarkens; $B=$ bij biggen; $D=b i j$ drachtige (en guste) zeugen; $K=$ bij kraamzeugen

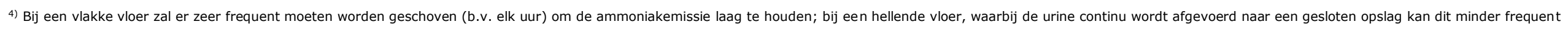
zijn (b.v. 4x/dag).

5) Middelgrote verbouwkosten, alleen bij een goed ontmestings-systeem (b.v. aanwezig rioleringssysteem), anders grote verbouwkosten

6) Als roosters niet vastliggen, anders grote renovatie

7) Alleen bij bolle vloeren met goed afvoersysteem

8) Bij een verlaging van het eiwitgehalte met $25 \mathrm{~g} / \mathrm{kg}$.

9) $16 \%$ ammoniakreductie bij $1 \%$ toevoeging benzoëzuur aan het voer.

10) Driekantroosters zijn minder geschikt voor drachtige zeugen, eventueel zou een deel van de roostervloer, waar naar verwachting veel wordt gemest, als driekantrooster kunnen worden uitgevoerd.

11) Bij aanwezigheid centraal aan- en afvoerkanaal lucht; nog verder onderzoek nodig.

12) Ook combinaties met andere luchtwassers zijn mogelijk (reducties gelijk aan die opgenomen in de Rav-lijst). 


\subsection{Combinaties van brongerichte maatregelen}

In deze paragraaf zal ingegaan worden op vraag 4:

4. 'Welke brongerichte maatregelen kunnen in bestaande varkensstallen gecombineerd/gestapeld worden en wat zijn de potentiële emissiereducties, uitgesplitst naar de vier diercategorieën?'

Maatregelen zijn vooral goed te combineren als ze inwerken op verschillende bronnen. Daarom zijn maatregelen die de kelderemissie reduceren heel goed te combineren met maatregelen die de vloeremissie reduceren. Voermaatregelen, zoals verlaging van het eiwitgehalte, kunnen met alle maatregelen worden gecombineerd.

Echter, verlaging van het eiwitgehalte is minder interessant als de ammoniakemissie al heel sterk wordt beperkt door andere maatregelen. Specifieke fijnstofmaatregelen, zoals negatieve ionisatie of olienippel, zijn met alle andere maatregelen te combineren. Alleen de fijnstofreductie wordt door deze maatregelen beïnvloed.

In tabel 2 zijn de meest logische combinaties opgenomen voor integrale emissiereductie. Uit de tabel komt naar voren dat heel veel maatregelen te combineren zijn met een optimale hokinrichting waar het lig- en mestgedrag goed gestuurd kan worden, waardoor een water- en mestkanaal kan worden toegepast. De driekantroosters op het mestkanaal zorgen voor een extra ammoniakreductie.

Driekantroosters zijn minder geschikt voor guste en drachtige zeugen in groepen. Dit vanwege het feit dat op metalen roosters onvoldoende slijtage van klauwen plaatsvindt. Daarnaast heeft de zeug onvoldoende grip op de in het algemeen gladdere metalen roosters. Beiden kunnen leiden tot meer kreupele zeugen wat niet gewenst is. Eventueel zou wel een deel van de roostervloer, daar waar de dieren naar verwachting veel mesten, uitgerust kunnen worden met een driekantrooster. Uit onderzoek zal moeten blijken of de zeugen dit rooster ook daadwerkelijk gebruiken om te mesten. Het zou kunnen, omdat ze voldoende ruimte hebben, dat ze een betonnen (rooster)vloer prefereren voor het mesten boven de driekant roostervloer. Bij opvang van de mest in ammoniakvrije of aangezuurde vloeistof is het aan te bevelen om ook de mest in een eventueel aanwezig waterkanaal hierin op te vangen. Dus dan praten we niet meer over een apart water- en mestkanaal. De stofreductiesystemen negatieve ionisatie en olienippel kunnen met alle andere systemen worden gecombineerd.

In tabel 3 worden de kansrijke combinaties van de tussenvorm van brongerichte maatregelen weergegeven. Onderafzuiging van de lucht is vooral goed te combineren met een water- en mestkanaal en driekantroosters. Negatieve ionisatiesystemen kan met alle systemen worden gecombineerd. 
Tabel 2 Kansrijke combinaties van brongerichte maatregelen voor integrale emissiereductie uit bestaande stallen, met een inschatting van de emissiereducties. Opmerking: de aangegeven emissiereducties zijn indicatief, afgerond op 5\%, in het algemeen nog niet gemeten en gebaseerd op een optimale werking van het systeem. Voor ammoniak zijn de schattingen vooral gebaseerd op modelberekeningen en voor geur, methaan en fijnstof vooral op expertkennis.

\begin{tabular}{|c|c|c|c|c|c|c|c|}
\hline Brongerichte maatregel & Combi met & $\begin{array}{l}\mathrm{NH} 3 \\
(\%)\end{array}$ & $\begin{array}{l}\text { Geur } \\
(\%)\end{array}$ & $\begin{array}{l}\text { Methaa } \\
\mathrm{n} \\
(\%)\end{array}$ & $\begin{array}{l}\text { Fijnstof } \\
(\%)\end{array}$ & $\begin{array}{l}\text { Effect op } \\
\text { luchtkwaliteit } \\
\text { in stal }^{1}\end{array}$ & $\begin{array}{l}\text { Categorieë } \\
\mathrm{n}^{2}\end{array}$ \\
\hline $\begin{array}{l}\text { Mestpannen met schuine wanden ( } 50 \% \text { reductie emit. } \\
\text { opp.); wekelijks mestverwijderen }\end{array}$ & $\begin{array}{l}\text { Water- en mestkanaal en } \\
\text { driekantroosters }\end{array}$ & $65 \%$ & $60 \%$ & $80 \%$ & $20 \%$ & +++ & Alle $^{3}$ \\
\hline $\begin{array}{l}\text { Mestpannen met schuine wanden ( } 50 \% \text { reductie emit. } \\
\text { opp.); wekelijks mestverwijderen }\end{array}$ & $\begin{array}{l}\text { Water- en mestkanaal en } \\
\text { driekantroosters en mestkoeling }\end{array}$ & $80 \%$ & $65 \%$ & $80 \%$ & $20 \%$ & +++ & Alle $^{3}$ \\
\hline $\begin{array}{l}\text { Opvang en spoelen met ammoniakvrije en geurarme } \\
\text { vloeistof (water of dunne fractie na behandeling) }\end{array}$ & Driekantroosters & $80 \%$ & $65 \%$ & $90 \%$ & $20 \%$ & +++ & $\mathrm{V}, \mathrm{B}, \mathrm{K}$ \\
\hline Opvang en spoelen met zure vloeistof & Driekantroosters & $85 \%$ & $20 \%$ & $90 \%$ & $20 \%$ & +++ & $\mathrm{V}, \mathrm{B}, \mathrm{K}$ \\
\hline $\begin{array}{l}\text { Dagontmesting door spoelen met verse mest; } \\
\text { verkleining emitterend mestoppervlak }(67 \%) \text {; koeling } \\
\left(<15^{\circ} \mathrm{C}\right)\end{array}$ & $\begin{array}{l}\text { Water- en mestkanaal en } \\
\text { driekantroosters }\end{array}$ & $80 \%$ & $65 \%$ & $90 \%$ & $20 \%$ & +++ & Alle $^{3}$ \\
\hline Aanzuren van mest $(\mathrm{pH}<6 ;$ Deens systeem) & $\begin{array}{l}\text { Water- en mestkanaal en } \\
\text { driekantroosters }\end{array}$ & $85 \%$ & $20 \%$ & $90 \%$ & $20 \%$ & +++ & $\mathrm{Alle}^{3}$ \\
\hline $\begin{array}{l}\text { Opvang mest in water i.c.m. mestscheiding (dunne } \\
\text { fractie eigen grond) }\end{array}$ & $\begin{array}{l}\text { Water- en mestkanaal en } \\
\text { driekantroosters }\end{array}$ & $75 \%$ & $30 \%$ & $30 \%$ & $20 \%$ & +++ & Alle $^{3}$ \\
\hline $\begin{array}{l}\text { Conditionering inkomende lucht met warmtewisselaar } \\
\text { en verhoging minimum ventilatie, i.c.m. chemische } \\
\text { luchtwasser } 95 \%{ }^{4}\end{array}$ & $\begin{array}{l}\text { Water- en mestkanaal en } \\
\text { driekantroosters }\end{array}$ & $95 \%$ & $50 \%$ & $20 \%$ & $50 \%$ & +++ & $\mathrm{Alll}^{3}$ \\
\hline Olienippel & $\begin{array}{l}\text { kan met alle systemen worden } \\
\text { gecombineerd }\end{array}$ & $0 \%$ & $0 \%$ & $0 \%$ & $65 \%$ & ++ & $V, B, D$ \\
\hline
\end{tabular}

1) 0 = geen effect; +/- = effect onbekend; + = gematigd positief; ++ = positief; +++ = zeer positief

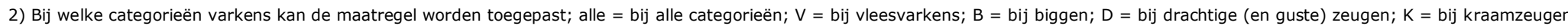

3) Driekantroosters zijn minder geschikt voor drachtige zeugen, eventueel zou een deel van de roostervloer, waar naar verwachting veel wordt gemest, als driekantrooster kunnen worden uitgevoerd. Het is ook vaak moeilijk om een water- en mestkanaal te implementeren bij drachtige zeugen. Wel kunnen schuine wanden in de mestkanalen worden aangebracht.

4) Ook combinaties met andere luchtwassers zijn mogelijk (reducties gelijk aan die opgenomen in de Rav-lijst). 
Tabel 3 Kansrijke tussenvormen van brongerichte maatregelen voor integrale emissiereductie uit bestaande stallen, met een inschatting van de emissiereducties. Opmerking: de aangegeven emissiereducties zijn indicatief, afgerond op 5\%, in het algemeen nog niet gemeten en gebaseerd op een optimale werking van het systeem. Voor ammoniak zijn de schattingen vooral gebaseerd op modelberekeningen en voor geur, methaan en fijnstof vooral op expertkennis.

\begin{tabular}{|c|c|c|c|c|c|c|c|}
\hline Tussenvormen brongerichte maatregelen & Combi met & $\begin{array}{l}\mathrm{NH3} \\
(\%)\end{array}$ & $\begin{array}{l}\text { Geur } \\
(\%)\end{array}$ & $\begin{array}{l}\text { Methaa } \\
\text { n } \\
(\%)\end{array}$ & $\begin{array}{l}\text { Fijnstof } \\
(\%)\end{array}$ & $\begin{array}{l}\text { Effect op } \\
\text { luchtkwaliteit } \\
\text { in stal }{ }^{1}\end{array}$ & $\begin{array}{l}\text { Categorieë } \\
n^{2}\end{array}$ \\
\hline \multicolumn{8}{|l|}{$\begin{array}{l}\text { Onderafzuiging van de stallucht onder de roostervloer } \\
\text { i.c.m. een luchtwasser }\end{array}$} \\
\hline $\begin{array}{l}\text { Luchtafzuiging volledig/gedeeltelijk onder de roostervloer; } \\
\text { volledig wassen; } 95 \% \text { chemische wasser }\end{array}$ & $\begin{array}{l}\text { Water- en mestkanaal en } \\
\text { driekantroosters }\end{array}$ & $95 \%$ & $40 \%$ & $25 \%$ & $50 \%$ & +++ & $\mathrm{Alle}^{3}$ \\
\hline $\begin{array}{l}\text { Luchtafzuiging volledig/gedeeltelijk onder de roostervloer; } \\
\text { volledig wassen; } 70 \% \text { biologische wasser }\end{array}$ & $\begin{array}{l}\text { Water- en mestkanaal en } \\
\text { driekantroosters }\end{array}$ & $85 \%$ & $55 \%$ & $25 \%$ & $80 \%$ & +++ & Alle $^{3}$ \\
\hline $\begin{array}{l}\text { Luchtafzuiging volledig/gedeeltelijk onder de roostervloer; } \\
\text { volledig wassen; } 85 \% \text { gecombineerde wasser }\end{array}$ & $\begin{array}{l}\text { Water- en mestkanaal en } \\
\text { driekantroosters }\end{array}$ & $90 \%$ & $55 \%$ & $25 \%$ & $85 \%$ & +++ & Alle $^{3}$ \\
\hline $\begin{array}{l}\text { Gedeeltelijk onder de roostervloer (min. ventilatie); gedeeltelijk } \\
\text { wassen; } 95 \% \text { chemische wasser }\end{array}$ & $\begin{array}{l}\text { Water- en mestkanaal en } \\
\text { driekantroosters }\end{array}$ & $80 \%$ & $35 \%$ & $25 \%$ & $35 \%$ & +++ & Alle $^{3}$ \\
\hline $\begin{array}{l}\text { Gedeeltelijk onder de roostervloer ( } \mathrm{min} \text {. ventilatie); gedeeltelijk } \\
\text { wassen; } 70 \% \text { biologische wasser }\end{array}$ & $\begin{array}{l}\text { Water- en mestkanaal en } \\
\text { driekantroosters }\end{array}$ & $75 \%$ & $50 \%$ & $25 \%$ & $50 \%$ & +++ & Alle $^{3}$ \\
\hline $\begin{array}{l}\text { Gedeeltelijk onder de roostervloer (min. ventilatie); gedeeltelijk } \\
\text { wassen; } 85 \% \text { gecombineerde wasser }\end{array}$ & $\begin{array}{l}\text { Water- en mestkanaal en } \\
\text { driekantroosters }\end{array}$ & $75 \%$ & $50 \%$ & $25 \%$ & $50 \%$ & +++ & Alle $^{3}$ \\
\hline \multicolumn{8}{|l|}{ Specifieke stofreductie methoden } \\
\hline Negatieve ionisatiesysteem & $\begin{array}{l}\text { kan met alle systemen } \\
\text { worden gecombineerd }\end{array}$ & $0 \%$ & $0 \%$ & $0 \%$ & $40 \%$ & + & Alle \\
\hline
\end{tabular}

1) 0 = geen effect; +/- = effect onbekend; + = gematigd positief; ++ = positief; +++ = zeer positief

2) Bij welke categorieën varkens kan de maatregel worden toegepast; alle = bij alle categorieën; $V=$ bij vleesvarkens; $B=$ bij biggen; $D=$ bij drachtige (en guste) zeugen; $K=$ bij kraamzeugen

3) Driekantroosters zijn minder geschikt voor drachtige zeugen, eventueel zou een deel van de roostervloer, waar naar verwachting veel wordt gemest, als driekantrooster kunnen worden uitgevoerd. Het is ook vaak moeilijk om een water- en mestkanaal te implementeren bij drachtige zeugen. Wel kunnen schuine wanden in de mestkanalen worden aangebracht. 


\subsection{Combinaties van brongerichte maatregelen en nageschakelde technieken}

In deze paragraaf zal ingegaan worden op vraag 5 :

5. 'Welke nageschakelde technieken kunnen gecombineerd worden met brongerichte maatregelen in bestaande varkensstallen en wat zijn de potentiële emissiereducties, uitgesplitst naar de vier diercategorieën?'

Nageschakelde technieken kunnen in principe met alle bronmaatregelen worden gecombineerd. Ze zijn echter vooral interessant in de volgende combinaties:

- In combinatie met onderafzuiging van stallucht; dit vergt echter nog wel enig onderzoek en ontwikkeling voor een juiste uitvoering in staltypen die in Nederland gebruikelijk zijn. De luchtstroming in de stal is hierbij belangrijk. Hiervoor kunnen simulaties worden gemaakt met luchtstromingsmodellen om de optimale locaties van afzuigen te bepalen. Deze ontwerpen zullen vervolgens gevalideerd moeten worden.

- In combi met goede klimatisering door conditionering van de inkomende lucht, waardoor de minimumventilatie kan worden verhoogd zonder extra verwarmingskosten. Indien de inkomende lucht ook gekoeld kan worden in de zomer, kan de maximale ventilatie worden verlaagd en kan worden volstaan met een kleinere luchtwasser.

Door deze combinaties worden niet alleen de emissies naar buiten gereduceerd, maar wordt tevens de luchtkwaliteit in de stal verbeterd. De effecten van deze combinaties op de emissiereducties en luchtkwaliteit in de stal zijn in par. 3.3, tabel 2 reeds ingeschat.

\subsection{Initiatieven in Nederland en het buitenland}

In deze paragraaf zal ingegaan worden op vragen 6, 7 en 8:

6. 'Welke initiatieven in Nederland en het buitenland zijn er die toepasbaar zijn in bestaande stallen, uitgesplitst naar de vier diercategorieën? Maak daarbij gebruik van het overzicht Stalsystemen in de conceptfase van provincie Noord-Brabant.'

7. 'In welke fase van de innovatiecyclus bevinden deze initiatieven zich? i. Ideevorming, ii. Ontwikkeling prototype, iii. Implementatie prototype (testen, valideren, onderzoek, doormeten), iv. Marktintroductie/uitrol (praktijkrijp, wettelijk erkend (Rav, Rgv)).'

8. 'Wat is er nodig om deze initiatieven verder te brengen? (Onderzoek, testen/valideren op praktijkbedrijven, metingen, wettelijke erkenning, stimuleren marktintroductie/demonstratie, uitrol).'

In tabel 4 worden de verschillende initiatieven weergegeven vanuit het bedrijfsleven in binnen- en buitenland voor reductie van emissies uit varkensstallen. In deze tabel is een indicatieve inschatting gegeven van het effect van het systeem op de verschillende emissies, waarbij opgemerkt moet worden dat de ingeschatte reducties gebaseerd zijn op een optimale werking van het systeem. Verder is in deze tabel weergegeven in welke fase van de innovatiecyclus het systeem zich bevindt. In de laatste kolom van deze tabel is aangegeven hoe deze initiatieven verder te brengen zijn, zodat ze uitgerold kunnen worden in de praktijk. 
Tabel 4 Kansrijke initiatieven voor integrale emissiereductie uit bestaande en nieuw te bouwen stallen, met een inschatting van de emissiereducties en effect op de luchtkwaliteit. Tevens is aangegeven voor welke categorieën varkens deze initiatieven geschikt zijn, in welke fase van innovatie deze initiatieven zich bevinden en wat er nog nodig is om dit initiatief verder uit te rollen in de praktijk. Opmerking: de aangegeven emissiereducties zijn indicatief, afgerond op 5\%, in het algemeen nog niet gemeten en gebaseerd op een optimale werking van het systeem. Voor ammoniak zijn de schattingen vooral gebaseerd op modelberekeningen en voor geur, methaan en fijnstof vooral op expertkennis.

\begin{tabular}{|c|c|c|c|c|c|c|c|c|c|}
\hline Initiatief & Belangrijkste principes & $\begin{array}{l}\text { NH3 } \\
(\%)\end{array}$ & $\begin{array}{l}\text { Geur } \\
(\%)\end{array}$ & $\begin{array}{l}\text { Methaan } \\
(\%)\end{array}$ & $\begin{array}{l}\text { Fijnstof } \\
(\%)\end{array}$ & $\begin{array}{l}\text { Lucht- } \\
\text { kwaliteit } \\
\text { stal }^{1}\end{array}$ & $\begin{array}{l}\text { Catego- } \\
\text { rieën }{ }^{2}\end{array}$ & Fase $^{3}$ & Nodig \\
\hline Dagontmesting & $\begin{array}{l}\text { Verkleining emitterend oppervlak door veel dichte } \\
\text { vloer en schuine wanden; water- en mestkanaal; } \\
\text { mestkoeling; sproeien schuine wanden; } \\
\text { dagontmesting; driekantroosters }\end{array}$ & $80 \%$ & $60 \%$ & $90 \%$ & $0 \%$ & +++ & alle $^{5}$ & $\mathrm{iii}$ & M \\
\hline $\begin{array}{l}\text { Deens systeem } \\
\text { aanzuren }\end{array}$ & $\begin{array}{l}\text { Scheiding mest; aanzuren dunne fractie en } \\
\text { terugzetten in mestput; driekantroosters }\end{array}$ & $85 \%$ & $20 \%$ & $90 \%$ & $20 \%$ & +++ & alle $^{5}$ & $\mathrm{iii}$ & $\mathrm{O}, \mathrm{T}, \mathrm{M}$ \\
\hline ZERO-STAL & $\begin{array}{l}\text { Mestscheiding, ammonia retention technique (ART), } \\
\text { ammoniakarme vloeistof in mestkanaal, } \\
\text { driekantroosters }\end{array}$ & $85 \%$ & $65 \%$ & $90 \%$ & $20 \%$ & +++ & alle $^{5}$ & iii & $\mathrm{O}, \mathrm{T}, \mathrm{M}$ \\
\hline $\begin{array}{l}\text { Koude } \\
\text { plasmatechnologie }\end{array}$ & $\begin{array}{l}\text { Koude plasmatechnologie, circulatie lucht }+ \text { end of } \\
\text { pipe reiniging }{ }^{6}\end{array}$ & $95 \%$ & $90 \%$ & $90 \%$ & $90 \%$ & +++ & alle & ii & 0 \\
\hline $\begin{array}{l}\text { Ammoniakarme } \\
\text { vloeistof }\end{array}$ & $\begin{array}{l}\text { Mestscheiding, beluchten, ammoniakarme vloeistof } \\
\text { in mestkanaal, driekantroosters }\end{array}$ & $80 \%$ & $65 \%$ & $90 \%$ & $20 \%$ & +++ & $\mathrm{alle}^{5}$ & iii & $\mathrm{T}, \mathrm{M}$ \\
\hline Mestschuif & $\begin{array}{l}\text { Mestschuif over gecoate hellende vloer onder } \\
\text { rooster, coating van vloeren en wanden }\end{array}$ & $65 \%$ & $60 \%$ & $90 \%$ & $10 \%$ & +++ & alle & $\mathrm{iii}$ & $\mathrm{T}, \mathrm{M}$ \\
\hline $\begin{array}{l}\text { Pig on the moon } \\
\text { (Denemarken) }\end{array}$ & $\begin{array}{l}\text { Mestpan met (gedeeltelijke) onderafzuiging lucht } \\
\text { i.c.m. luchtwasser }\end{array}$ & $80 \%$ & $30 \%$ & $50 \%$ & $20 \%$ & +++ & alle & iii & $\mathrm{T}, \mathrm{M}$ \\
\hline Varkenstoilet & Varkenstoilet met zandbed & $85 \%$ & $70 \%$ & $90 \%$ & $50 \%$ & +++ & alle $^{6}$ & ii & $0, T$ \\
\hline Luchtconditionering & $\begin{array}{l}\text { Gekoelde luchtinlaat in combinatie met warmtepomp } \\
\text { voor energie neutrale stal }\end{array}$ & $15 \%$ & $15 \%$ & $0 \%$ & $0 \%$ & ++ & alle $^{7}$ & iv & $\mathrm{s}$ \\
\hline Vloerkoeling & $\begin{array}{l}\text { Comfort vloer bij vleesvarkens en biggen. } \\
\text { Vloerkoeling in combinatie met warmtepomp }\end{array}$ & $10 \%$ & $10 \%$ & $0 \%$ & $0 \%$ & + & $\mathrm{V}, \mathrm{B}$ & iv & $\mathrm{s}$ \\
\hline Gekoelde mestpan & $\begin{array}{l}\text { Gekoelde mestpannen in combi met driekant } \\
\text { roosters }\end{array}$ & $75 \%$ & $60 \%$ & $80 \%$ & $0 \%$ & +++ & alle $^{5}$ & $\mathrm{iii}^{8}$ & $T, M^{8}$ \\
\hline
\end{tabular}




\begin{tabular}{|c|c|c|c|c|c|c|c|c|c|}
\hline Initiatief & Belangrijkste principes & $\begin{array}{l}\mathrm{NH3} \\
(\%)\end{array}$ & $\begin{array}{l}\text { Geur } \\
(\%)\end{array}$ & $\begin{array}{l}\text { Methaan } \\
(\%)\end{array}$ & $\begin{array}{l}\text { Fijnstof } \\
(\%)\end{array}$ & $\begin{array}{l}\text { Lucht- } \\
\text { kwaliteit } \\
\text { stal }^{1}\end{array}$ & $\begin{array}{l}\text { Catego- } \\
\text { rieën }{ }^{2}\end{array}$ & Fase $^{3}$ & Nodic \\
\hline Luchtrecirculatie & $\begin{array}{l}\text { Gedeeltelijke recirculatie van lucht in combi met } \\
\text { luchtzuivering en luchtconditionering }\end{array}$ & $90 \%$ & $50 \%$ & $0 \%$ & $85 \%$ & ++ & alle & ii & $\mathrm{O}$ \\
\hline Negatieve ionisatie & Negatieve ionisatie & $0 \%$ & $0 \%$ & $0 \%$ & $50 \%$ & + & alle & iii & $T, M$ \\
\hline VAROND & Varkenstoilet in grote groepen & $? \%$ & $? \%$ & $? \%$ & $? \%$ & $?$ & $V, B, D$ & ii & 0 \\
\hline Strostal zeugen & $\begin{array}{l}\text { Strostal met gescheiden opvang mest en urine bij } \\
\text { drachtige zeugen }\end{array}$ & $? \%$ & $? \%$ & $? \%$ & $? \%$ & $?$ & $\mathrm{D}$ & iv & M \\
\hline Foliepan & $\begin{array}{l}\text { Foliepan met continue verwijdering van feces en } \\
\text { urine }\end{array}$ & $40 \%$ & $40 \%$ & $80 \%$ & $0 \%$ & + & alle & ii & $\mathrm{O}$ \\
\hline Mestband & Bolle mestband / V-vormige mestband & $60 \%$ & $60 \%$ & $90 \%$ & $0 \%$ & ++ & $\mathrm{V}, \mathrm{D}$ & iii & $M$ \\
\hline TRAC (Frankrijk) & V-vormige mestgoot met mestschuif & $50 \%$ & $50 \%$ & $90 \%$ & $0 \%$ & ++ & alle & iv & M \\
\hline
\end{tabular}

1) 0 = geen effect; $+/-=$ effect onbekend; $+=$ gematigd positief; $++=$ positief; $+++=$ zeer positief

2) Bij welke categorieën varkens kan de maatregel worden toegepast; alle = bij alle categorieën; $V=$ bij vleesvarkens; $B=$ bij biggen; $D=$ bij drachtige (en guste) zeugen; $K=$ bij kraamzeugen

3) Fase: $\mathrm{i}$ = ideevorming; ii = ontwikkeling prototype; iii = implementatie prototype (testen, valideren, onderzoek, doormeten); iv. = marktintroductie/uitrol (praktijkrijp, wettelijk erkend (Rav, Rgv))

4) Nodig: $\mathrm{O}=$ onderzoek en ontwikkeling; $\mathrm{T}$ = testen / valideren op praktijkbedrijven; $\mathrm{M}=$ metingen / wettelijke erkenning; $\mathrm{S}=$ stimuleren marktintroductie / demonstratie / uitrol

5) Driekantroosters zijn minder geschikt voor drachtige zeugen; wel kan een deel van de roostervloer, daar waar naar verwachting veel wordt gemest, worden voorzien van driekantroosters.

6) Niet zeker of in deze uitvoering ook een end of pipe reiniging wordt toegepast. Bij alleen circulatie in de stal, is de reductie sterk afhankelijk van de mate van luchtcirculatie, maar zal dan in ieder geval (beduidend) lager zijn dan de aangegeven reducties.

6) De reducties worden alleen gehaald bij een optimaal functioneren van dit systeem. Dit betekent dat het zandbed niet bevuild mag worden met mest en urine.

7) De verbetering van de luchtkwaliteit in de stal wordt vooral bereikt door meer te ventileren in de winter.

8) Bij kraamzeugen fase iv en benodigd $S$ 


\section{Discussie}

Op hoofdlijnen kan gesteld worden dat de verschillende emissies vooral als volgt bij de bron beperkt kunnen worden:

- Ammoniak:

- Frequente en volledige verwijdering van mest (urine bij voorkeur continu afvoeren)

Opvang in ammoniakvrije of zure vloeistof

Verkleining emitterend oppervlak

Koelen van mest

Aanzuren van mest

Laag eiwitgehalte en/of verzurend voer

Schone vloeren

- Geur:

- Frequente en volledige verwijdering van mest (urine bij voorkeur continu afvoeren)

Opvang in geurvrije vloeistof

Koelen van mest

Laag eiwitgehalte

Schone vloeren

- Methaan:

- Frequente verwijdering van mest (dagelijks / wekelijks)

- Aanzuren / formaldehyde (methaanvormende bacteriën worden gedood)

- Koelen van mest

- Fijn stof:

- Schone vloeren

- Specifieke stofmaatregelen

Daarnaast kunnen ammoniak, geur en fijnstof ook gereduceerd worden door een tussenvorm van brongericht, namelijk via (gedeeltelijke) onderafzuiging van de lucht in combinatie met een luchtwasser.

Met betrekking tot het reduceren van methaan door het doden van bacteriën in de mest moet opgemerkt worden dat formaldehyde geen goede oplossing is om toe te passen in stallen, omdat er indicaties zijn dat deze stof bij inademing kankerverwekkend kan zijn. Bij aanzuren moet de $\mathrm{pH}$ sterk worden verlaagd $(\mathrm{pH}<4.0)$ om bacteriën te doden. Dit laatste is uit milieu-oogpunt en uit corrosie overwegingen niet aantrekkelijk. Daarom blijven voor methaan eigenlijk twee opties over: frequent verwijderen van de mest naar een buitenopslag of koelen van de mest. In beide gevallen moet voorkomen worden dat de methaan in de buitenopslag alsnog gevormd wordt en emitteert. Het voordeel van buitenopslag is dat de gemiddelde temperatuur beduidend lager is dan in de stal, waardoor de vorming van methaan minder snel verloopt. De aangegeven reducties in de stal van ca. $90 \%$ zullen echter voor een deel teniet worden gedaan als de mest vervolgens langdurig in een silo buiten de stal wordt opgeslagen. Opslag in een biogasinstallatie of een snelle verdere verwerking van de mest wordt daarom aanbevolen.

Voor ammoniak en in iets mindere mate ook voor geur is snelle verwijdering alleen niet voldoende. Voor een sterke reductie van deze gassen moet de mest ook volledig worden verwijderd en bij toepassing van mestschuiven of mestbanden worden de urine en feces bij voorkeur gescheiden afgevoerd. Hierbij wordt de urine continu afgevoerd en de feces een aantal keren per dag. Sterke verdunning van de verse mest door opvang in ammoniak- en geurvrije vloeistof kunnen de emissies van ammoniak en geur ook aanzienlijk beperken. De huidige luchtwassers zijn zeer effectief voor het verwijderen van ammoniak, echter minder voor geur. Met luchtwassers kan alleen een betere luchtkwaliteit op dierniveau worden gecreëerd door een deel van de lucht onder de roostervloer in het mestkanaal af te zuigen. Koelen van mest, laag eiwitgehalte van het voer en schone vloeren zijn effectieve methoden om de emissies van zowel ammoniak als geur te beperken. Verkleining van het 
emitterend oppervlak, het aanzuren van mest en het toepassen van verzurende voeders zijn vooral van belang voor ammoniakreductie.

De fijnstof emissie wordt niet beïnvloed door maatregelen in de mestkelder. Maatregelen om fijnstof te reduceren beperken zich tot luchtwassing, schone vloeren en de specifieke stofreductiemethoden zoals een olienippel of een ionisatiesysteem.

Het voorgaande in ogenschouw nemend zijn er een aantal maatregelen die gecombineerd een integrale reductie bij de bron van zowel ammoniak, geur, methaan als fijnstof kunnen bewerkstelligen:

1. Frequente en volledige verwijdering van mest (urine bij voorkeur continu afvoeren) in combinatie met schone vloeren en een specifieke stofreductiemaatregel.

2. Opvang in ammoniak- en geurvrije of -arme vloeistof in combinatie met schone vloeren en een specifieke stofreductiemaatregel.

3. Koelen van de mest in combinatie met schone vloeren en een specifieke stofreductiemaatregel.

Ad 1.

Voor frequente en volledige verwijdering van mest kunnen mestpannen, mestgoten of mestschuiven worden gebruikt. Mestbanden kunnen ook worden toegepast, maar die zijn minder goed in te passen in bestaande stallen. Dit geldt in iets mindere mate ook voor mestschuiven. Een nieuw initiatief waarbij een robotschuif de mest opzuigt zou misschien wel goed ingepast kunnen worden in bestaande stallen, maar daar is eerst verder onderzoek voor nodig. Mestpannen en mestgoten zijn niet per definitie emissiearm voor ammoniak. Om dit te bereiken zijn extra maatregelen nodig zoals het toepassen van water- en mestkanalen (bij mestpannen wordt dit voor het gemak ook even zo genoemd), verkleining van het emitterend oppervlak via schuine wanden en koeling van het mestkanaal. Eventueel kan daar nog verdunning van de mest aan toe worden gevoegd. Mestschuiven geven vooral een ammoniak-beperking bij directe scheiding tussen urine en feces en wanneer de schuifvloer zeer glad wordt uitgevoerd, al dan niet in combinatie met toepassing van een biocide (desinfectiemiddel voor het doden van bacteriën) of ureaseremmer (schakelt de werking van het enzym uit).

Ad 2.

Als ammoniak- en geurvrije of -arme vloeistof kan zuiver water worden gebruikt. Dit kan aantrekkelijk zijn voor bedrijven met voldoende eigen grond. Door de verse mest op te vangen in water en deze verdunde mest buiten de stal te scheiden in dik en dun, kan vervolgens de dunne fractie op eigen grond worden gebruikt en de dikke fractie worden afgevoerd. In andere gevallen wordt de dunne mest buiten de stal gescheiden en wordt de dunne fractie ammoniak- en geurvrij of -arm gemaakt. Dit kan b.v. gerealiseerd worden door beluchten van de dunne fractie. De ammonium- $\mathrm{N}$ vervliegt dan voor een belangrijk deel via nitrificatie en denitrificatie stappen naar de lucht in de vorm van stikstofgas $\left(\mathrm{N}_{2}\right)$. Bij dit proces komt vrijwel altijd enige lachgas vrij $\left(\mathrm{N}_{2} \mathrm{O}\right)$. De mate waarin dit gebeurt is sterk afhankelijk van de procescontrole. Procesbeheersing is bij de verdere ontwikkeling en toepassing van deze techniek dan ook een belangrijke voorwaarde.

Ad 3.

Voor integrale reductie van emissies moet bij koelen van de mest niet alleen het oppervlak van de mest worden gekoeld maar alle mest. Oppervlaktekoeling is voldoende voor ammoniakreductie, maar niet voor reducties van geur en methaan. Voor een sterke reductie van ammoniak, geur en methaan zou de mest eigenlijk nog verder moeten worden gekoeld dan de $15^{\circ} \mathrm{C}$ die nu wordt gehanteerd als maximum temperatuur voor het oppervlak van de mest. Om van mestkoeling een duurzaam systeem te maken zou de onttrokken warmte benut moeten kunnen worden (b.v. voor verwarming van biggenstallen, woonhuis).

Tussenvormen van brongerichte maatregelen, die wel zorgen voor een betere luchtkwaliteit op dierniveau (en mensniveau), maar waar niet de focus binnen dit innovatieprogramma op ligt, zijn: (gedeeltelijke) onderafzuiging van de lucht of gedeeltelijke recirculatie van lucht in combinatie met een luchtwasser en in combinatie met schone vloeren en een specifieke 
stofreductiemaatregel. Aangezien deze maatregelen geen effect hebben op de methaanemissie, is hier ook een aanvullende maatregel nodig, b.v. het regelmatig afvoeren van de mest.

Gedeeltelijke onderafzuiging van lucht is recent uitgebreid onderzocht in Denemarken. De resultaten daar zijn heel positief. Op VIC Sterksel hebben we dit systeem ook onderzocht en daar waren de resultaten minder goed. De oorzaak hiervan lag vooral in de wijze van ventileren. In Denemarken komt de lucht binnen via een geperforeerd plafond, terwijl dit in het onderzoek op VIC Sterksel, en in vrij veel stallen in Nederland, via een kanaal onder de voergang gebeurde. Een verschil in luchtstromingspatroon tussen beide luchtinlaten lijkt de belangrijkste oorzaak te zijn van de slechtere resultaten op VIC Sterksel. Goede ventilatieontwerpen met simulaties van de te verwachten luchtstromen zijn daarom noodzakelijk om de vuile kelderlucht effectief af te zuigen. In Denemarken wordt alleen de afgezogen lucht onder de roostervloer gewassen. Om voldoende emissiereductie te bewerkstelligen is het aan te bevelen om alle lucht door de luchtwasser te laten zuiveren. Vooral ook omdat in het andere geval hoge piekemissies van geur tijdens warme dagen kunnen ontstaan. Lucht kan na zuivering en conditionering ook weer gedeeltelijk worden terug gebracht in de stal. Hierdoor ontstaat een vrijwel gesloten stalsysteem. Er moet dan alleen voldoende lucht worden geventileerd om kooldioxide af te voeren en zuurstof aan te voeren. Dit geeft niet alleen een sterke reductie van de emissies naar buiten (door luchtwassing), maar tevens een zeer stabiel stalklimaat, aangezien de luchtcondities veel minder afhankelijk zijn van de buitencondities. Dit systeem staat echter nog in de kinderschoenen en verder onderzoek hiernaar is gewenst. Het vereist een zeer goed werkend systeem van luchtzuivering en conditionering.

Vervuilde vloeren kunnen de werking van emissiearme brongerichte maatregelen belangrijk verstoren. Met name de emissies van ammoniak, geur en fijnstof zullen dan toenemen. Schone vloeren zijn daarom uitgangspunt voor brongerichte emissiearme stallen. Ten opzichte van de huidige stallen zou dit nog verbeterd kunnen worden door:

- Het coaten van vloeren en wanden;

- Goed doorlatende roosters, zoals metalen driekantroosters al dan niet in combinatie met een mestspleet tegen de achterwand van het hok;

- $\quad$ Goede klimatisering en hokinrichting.

Bij het coaten van vloeren moet worden gewaarborgd dat de varkens er goed op kunnen lopen. Metalen driekantroosters hebben naast een goede mestdoorlaat tevens een lage urease-activiteit waardoor de ureum in de urine die achterblijft op de roostervloer minder snel wordt omgezet in ammoniak. Een goede hokinrichting is heel belangrijk voor het sturen van het lig- en mestgedrag van de varkens. Varkens zullen in het algemeen niet daar mesten waar ze eten en drinken en ook niet daar waar veel (andere) activiteit is. Ze zullen een rustige plek opzoeken in het hok. Bij trogvoedering is het mestgedrag minder goed te sturen dan bij voorraad voedering. Zeker bij brijvoedering in troggen is het risico op hokbevuiling groot. Een goede klimatisering is ook van essentieel belang voor goed lig- en mestgedrag van de dieren. Varkens zullen niet op een tochtige plek gaan liggen en bij hoge temperaturen (boven de comfortzone) zullen ze een koele plek opzoeken in het hok. Liggen op de roostervloer geeft vaak enige verkoeling, waardoor het risico op bevuiling van de dichte vloer sterk toeneemt. Conditionering van de inkomende lucht, zowel in de winter als in de zomer is daarom aan te bevelen. Sensoren die het stalklimaat op dierniveau monitoren kunnen hierbij ondersteunend werken. Een goede sturing van het lig- en mestgedrag kan ook bereikt worden door de ligvloer van de dieren te conditioneren afhankelijk van de behoefte, b.v. verwarmen in de winter en koelen in de zomer. De mate van koeling en verwarming is mede afhankelijk van het groeistadium of levenscyclus waarin de dieren zitten.

Naast schone vloeren, kan de fijnstofconcentratie op dierniveau vrijwel alleen nog worden gereduceerd via specifieke stofreductiemaatregelen, zoals een olienippel of een ionisatiesysteem. Beiden zijn op VIC Sterksel onderzocht en blijken effectief fijnstof te kunnen reduceren.

Voermaatregelen kunnen aanvullende reducties geven van de emissies, met name van ammoniak en geur. Het afstemmen van het eiwitgehalte in het voer op de behoefte van de (individuele) varkens is daarom belangrijk om ook via die weg reducties in emissies te bewerkstelligen. Methaanreducties 
zouden verkregen kunnen worden door zeer goed verteerbare voeders te maken. Dit past echter minder in het duurzaamheidsplaatje van varkens als afvalverwerkers.

Voornoemde brongerichte maatregelen voor emissiereductie van ammoniak, geur, methaan en fijnstof geven ook een sterke verbetering van de luchtkwaliteit op dierniveau. In bestaande stallen met luchtwassers kan dit ook worden bereikt door de minimum ventilatie (sterk) te verhogen. Dit dient dan echter gepaard te gaan met één of andere vorm van warmteterugwinning en hergebruik van deze warmte, omdat anders het energiegebruik zeer sterk zou stijgen. Dit geldt voor alle categorieën varkens. Op dit moment zijn er verschillende systemen op de markt om de warmte in de uitgaande lucht of in de mest terug te winnen en her te gebruiken voor verwarming van de inkomende lucht of van de afdelingen. Daarnaast zijn er ook systemen op de markt die gebruik maken van warmte- en koudeopslag in de bodem. Bij deze oplossing voor verbetering van de leefomgeving van de dieren, zijn de emissies naar buiten volledig gerelateerd aan de werking van de luchtwasser. De huidige luchtwassers geven geen reductie van de methaanemissie en de geurreductie is wisselend.

Voor renovatie van bestaande stallen is het van belang om inzicht te hebben in de leeftijd van de huidige stallen en welke typen stallen er aangepast zouden moeten / kunnen worden. Vanaf 1993 zijn op basis van het Convenant Groen Label (Stcrt. 1993, 21) emissiebeperkende systemen in stallen toegepast. Dit waren tot 2006 voornamelijk systemen met emissiebeperking aan de bron (koeling, schuine wanden, spoelen e.d.). Vanaf die tijd kwamen er chemische wassers in de lijst en op de markt. Deze werden vooral toegepast op locaties waar ammoniakemissie een probleem was. Vanaf 11-2007 werden met de ingang van de Wet geurhinder en Veehouderij emissiebeperkende systemen toegepast die ook ruimte gaven om uit te breiden als geur een probleem was (middels $V$-stacks berekeningen). Luchtwassers boden, naast ammoniakreductie, ook een oplossing voor problemen met geurhinder. Vanaf 1-1-2010 kwamen de eerste combi-wassers in de lijst. Deze gaven meer mogelijkheden om binnen de grenzen van geur en ammoniak uit te breiden. Daarnaast was vanaf die tijd het in Brabant verplicht om 85\% ammoniak te reduceren in het kader van de bescherming van de Natura 2000 gebieden. Vanaf die tijd werd elke nieuwe stal in Noord-Brabant uitgerust met een wasser. Vanaf 1-1-2013 moesten in het kader van Besluit huisvesting alle stallen voldoen aan een maximale norm van de emissie van ammoniak. Nieuwbouwstallen in Limburg moesten vanaf dat jaar ook de emissie met minimaal $85 \%$ reduceren.

\section{Ruwweg kan worden gesteld dat we drie categorieën stallen hebben:}

- Oude stallen van voor 1993 zonder emissiereductie systeem (traditioneel) : deze zullen na het beëindigen van de stoppersregeling voor een deel gesaneerd worden en voor een deel alsnog van een luchtwasser voorzien worden, tenzij er alternatieven zijn voor de luchtwasser.

- Stallen ruwweg tussen 1993 en 2007: deze hebben vooral een emissiebeperkend systeem in de put. Daarbij gaat het vooral om systemen met een water- en mestkanaal, al dan niet in combinatie met schuine wanden, koeldeksystemen en mestverdunning. Voor een deel zullen deze systemen inmiddels gecombineerd zijn met een luchtwasser, voor de rest zullen ze nog aangepast moeten worden.

- Stallen met luchtwassers (voor een deel zijn dit stallen van voor 1993 en 2008 omdat deze later in verband met geur- of ammoniakgrenzen een luchtwasser hebben gekregen). Vooral in Brabant en Limburg zijn na 2010 luchtwassers geplaatst.

Geschat \% dieren gehuisvest in de verschillende typen stallen:

- Traditionele stallen: 20-25\% van de dieren;

- Stallen met emissiebeperking bij de bron: 25-30\% van de dieren;

- Stallen met luchtwassers: 45-55 \% van de dieren.

Bronmaatregelen kunnen vooral toegepast worden in de volgende stallen:

- Alle stallen met emissiebeperking bij de bron die niet zijn uitgevoerd met een betonrooster. Dit geldt voor ongeveer de helft van de stallen, dus ca. 12,5 - 15\% van het totaal (vooral biggen- en kraamstallen komen in aanmerking). Stallen met luchtwassers zouden naar onderafzuiging kunnen worden omgebouwd. Hiervoor is echter meer onderzoek nodig om te bepalen hoe dit precies gerealiseerd kan worden, zodanig dat het systeem efficiënt de vuile lucht bij de bron afzuigt en de verbouwkosten acceptabel blijven. 


\section{$5 \quad$ Samenvattende conclusies}

De volgende gecombineerd maatregelen kunnen een integrale reductie bij de bron bewerkstelligen van zowel ammoniak, geur, methaan als fijnstof:

- Frequente en volledige verwijdering van mest via mestpannen, mestgoten of mestschuiven in combinatie met schone vloeren en een specifieke stofreductiemaatregel. Mestbanden kunnen ook worden toegepast, maar die zijn minder goed in te passen in bestaande stallen. Dit geldt in iets mindere mate ook voor mestschuiven. Bij mestpannen en mestgoten zijn aanvullende maatregelen nodig om ammoniak te reduceren zoals het toepassen van water- en mestkanalen, verkleining van het emitterend oppervlak en koeling van het mestkanaal (verdunning van de mest kan hier nog aan toe worden gevoegd). Bij mestschuiven wordt de urine bij voorkeur continu afgevoerd en worden de schuifvloeren glad gecoat of voorzien van een rubberen / plastic (geen pvc) toplaag. Om urease-vorming op de vloer tegen te gaan kunnen aanvullend urease-remmers of biocides worden gebruikt.

Initiatieven:

- Verkleining emitterend oppervlak door veel dichte vloer en schuine wanden; water-en mestkanaal; mestkoeling; sproeien schuine wanden; dagontmesting; driekantroosters;

- Mestschuif over gecoate hellende vloer onder rooster, coating van vloeren en wanden;

- Varkenstoilet met zandbed;

- Gekoelde mestpannen in combi met driekant roosters;

VAROND, varkenstoilet in grote groepen;

Foliepan met continue verwijdering van feces en urine;

Bolle mestbanden / V-vormige mestbanden;

TRAC, V-vormige mestgoot met mestschuif).

- Opvang in ammoniak- en geurvrije of -arme vloeistof in combinatie met schone vloeren en een specifieke stofreductiemaatregel. Hiervoor kan zuiver water worden gebruikt op bedrijven met veel eigen grond, waarbij de mest buiten de stal wordt gescheiden in dik en dun. De dikke mest wordt afgevoerd en de dunne fractie wordt op eigen grond toegepast. In andere gevallen wordt de dunne mest buiten de stal gescheiden en wordt de dunne fractie ammoniak- en geurvrij of -arm gemaakt. Dit kan b.v. gerealiseerd worden door beluchten van de dunne fractie.

Initiatieven:

- ZERO-STAL, mestscheiding, ammonia retention technique (ART), ammoniakarme vloeistof in mestkanaal, driekantroosters;

- Ammoniakarme vloeistof in mestkanaal, mestscheiding, beluchten, driekantroosters.

- Koeling van de volledige mest. Om een sterke reductie te bewerkstelligen voor zowel ammoniak, geur als methaan dient de volledige mest bij voorkeur nog sterker te worden terug gekoeld dan de $150 \mathrm{C}$ die nu geldt als maximale waarde voor ammoniakreductie. Voor het creëren van een duurzaam systeem zou de onttrokken warmte weer benut moeten kunnen worden.

Perspectiefvolle tussenvormen van brongerichte maatregelen zijn:

- Toepassing van luchtwassers met gedeeltelijke onderafzuiging van de lucht of gedeeltelijke (re)circulatie van lucht, waarbij alle lucht of een gedeelte van de lucht wordt gereinigd in combinatie met schone vloeren en een specifieke stofreductiemaatregel. Onderafzuiging van stallucht vergt echter nog wel onderzoek en ontwikkeling voor toepassing in staltypen die in Nederlandse gebruikelijk zijn. De luchtstroming in de stal is hierbij belangrijk. Hiervoor kunnen simulaties worden gemaakt met luchtstromingsmodellen om de optimale locaties van afzuigen te bepalen. Deze ontwerpen zullen vervolgens gevalideerd moeten worden.

Initiatieven:

- Aan onderafzuiging wordt veel gedaan in Denemarken (onderzoek + praktijkimplementatie)

- Koude plasmatechnologie, circulatie en reiniging van lucht in combinatie met end of pipe reiniging met dezelfde techniek;

- Gedeeltelijke recirculatie van lucht in combi met luchtzuivering en luchtconditionering. 
Vervuilde vloeren kunnen de werking van emissiearme brongerichte maatregelen belangrijk verstoren. Met name de emissies van ammoniak, geur en fijnstof zullen dan toenemen. Schone vloeren zijn daarom uitgangspunt voor brongerichte emissiearme stallen. Ten opzichte van de huidige stallen zou dit nog verbeterd kunnen worden door:

- Het coaten van vloeren en wanden;

- Goed doorlatende roosters, zoals metalen driekantroosters al dan niet in combinatie met een mestspleet tegen de achterwand van het hok;

- Goede klimatisering en hokinrichting.

Naast schone vloeren, kan de fijnstofconcentratie op dierniveau vrijwel alleen nog worden gereduceerd via specifieke stofreductiemaatregelen, zoals een olienippel of een ionisatiesysteem.

Voermaatregelen kunnen aanvullende reducties geven van de emissies, met name van ammoniak en geur. Het afstemmen van het eiwitgehalte in het voer op de behoefte van de (individuele) varkens is daarom belangrijk om ook via die weg reducties in emissies te bewerkstelligen.

Brongerichte maatregelen voor emissiereductie van ammoniak, geur, methaan en fijnstof geven ook een sterke verbetering van de luchtkwaliteit op dierniveau. In bestaande stallen met luchtwassers kan dit ook worden bereikt door de minimum ventilatie (sterk) te verhogen. Dit dient dan echter gepaard te gaan met één of andere vorm van warmteterugwinning en hergebruik van deze warmte, omdat anders het energiegebruik zeer sterk zou stijgen. Dit geldt voor alle categorieën varkens.

Initiatieven:

- Gekoelde luchtinlaat in combinatie met warmtepomp voor energie neutrale stal;

- Comfort vloer bij vleesvarkens en biggen. Vloerkoeling in combinatie met warmtepomp;

○ Verschillende bedrijven brengen systemen met warmteterugwinning op de markt.

Brongerichte emissiemaatregelen in de mestput zijn meestal gemakkelijker toe te passen bij biggenhokken en kraamhokken, vooral vanwege de lichtere vorm van hokinrichting en roostervloeren. Bij vleesvarkens en drachtige zeugen is dit in het algemeen lastiger vanwege de vaak zware hokinrichting, zoals betonroosters en betonnen hokinrichting. Daarnaast zijn betonnen roostervloeren vaak vast gestort aan de dichte vloer. In dat geval moet de gehele vloer met hokinrichting gesloopt worden met relatief zware machines om het materiaal uit de stal te halen of te verplaatsen. Dit zal via openingen in dak of muur moeten gebeuren. Veranderingen zijn bij deze diercategorieën dus vaak zeer ingrijpend. 


\section{Bijlage 1}

Groslijst van mogelijke brongerichte maatregelen (inclusief tussenvormen van brongericht) om emissies uit varkensstallen integraal te reduceren. De effecten op de emissiereducties (afgerond op 5\%) en het effect op de luchtkwaliteit in de stal zijn indicatief ingeschat. Tevens is aangegeven of de maatregel toepasbaar is in bestaande stallen en bij welke diercategorieën deze maatregel kan worden doorgevoerd.

\begin{tabular}{|c|c|c|c|c|c|c|c|}
\hline Brongerichte maatregel & $\begin{array}{l}\text { NH3-red. } \\
(\%)\end{array}$ & $\begin{array}{l}\text { Geurred. } \\
(\%)\end{array}$ & $\begin{array}{l}\text { Methaanred. } \\
(\%)\end{array}$ & $\begin{array}{l}\text { Fijnstofred. } \\
(\%)\end{array}$ & $\begin{array}{l}\text { Effect op } \\
\text { luchtkwaliteit } \\
\text { in stal }^{1}\end{array}$ & $\begin{array}{l}\text { Toepasbaar } \\
\text { in bestaande } \\
\text { stallen?2,3 }\end{array}$ & Categorieën ${ }^{3}$ \\
\hline \multicolumn{8}{|l|}{ Mest snel en volledig uit de stal } \\
\hline $\begin{array}{l}\text { Mestschuif over gecoate vlakke vloer met biocide / vlakke vloer } \\
\text { bekleed met rubber/polyethyleen/polypropyleen }\end{array}$ & $60 \%$ & $60 \%$ & $90 \%$ & $0 \%$ & ++ & Ren. & alle \\
\hline Mestbanden van polyethyleen of polypropyleen & $60 \%$ & $60 \%$ & $90 \%$ & $0 \%$ & ++ & Nee & $\mathrm{V}, \mathrm{D}$ \\
\hline $\begin{array}{l}\text { Mestpannen met schuine wanden ( } 50 \% \text { reductie emit. opp.); } \\
\text { wekelijks mestverwijderen }\end{array}$ & $40 \%$ & $40 \%$ & $80 \%$ & $0 \%$ & + & Ren. & alle \\
\hline $\begin{array}{l}\text { Foliepannen (continue mestverwijdering; } 1 \text { x/dag sproeien met } \\
\text { water en biocide) }\end{array}$ & $50 \%$ & $60 \%$ & $90 \%$ & $0 \%$ & ++ & Ren. & alle \\
\hline $\begin{array}{l}\text { Opvang en spoelen met ammoniakvrije en geurarme vloeistof } \\
\text { (water of dunne fractie na behandeling) }\end{array}$ & $65 \%$ & $60 \%$ & $90 \%$ & $0 \%$ & ++ & $\mathrm{Ja}$ & alle \\
\hline Opvang en spoelen met zure vloeistof & $65 \%$ & $20 \%$ & $90 \%$ & $0 \%$ & ++ & $\mathrm{Ja}$ & alle \\
\hline Opvang en spoelen met formaldehyde behandelde mestvloeistof & $65 \%$ & $20 \%$ & $90 \%$ & $0 \%$ & ++ & $\mathrm{Ja}$ & alle \\
\hline $\begin{array}{l}\text { Dagontmesting door spoelen met verse mest; verkleining } \\
\text { emitterend mestoppervlak }(67 \%) \text {; koeling }(<15 \circ \mathrm{C})\end{array}$ & $65 \%$ & $50 \%$ & $90 \%$ & $0 \%$ & ++ & Ren. & alle \\
\hline Aanzuren van mest $(\mathrm{pH}<6$; Deens systeem) & $70 \%$ & $0 \%$ & $90 \%$ & $0 \%$ & ++ & $\mathrm{Ja}^{7}$ & alle \\
\hline \multicolumn{8}{|l|}{ Verkleining emitterend oppervlak } \\
\hline Water- en mestkanaal & $35 \%$ & $20 \%$ & $0 \%$ & $0 \%$ & + & $\mathrm{Ja}^{4}$ & alle $e^{4}$ \\
\hline Schuine wanden & $15 \%$ & $0 \%$ & $0 \%$ & $0 \%$ & + & Ren. & alle \\
\hline Verkleining rooster- en kelderoppervlakte & $20 \%$ & $0 \%$ & $0 \%$ & $0 \%$ & + & Nee & alle \\
\hline
\end{tabular}




\begin{tabular}{|c|c|c|c|c|c|c|c|}
\hline Brongerichte maatregel & $\begin{array}{l}\text { NH3-red. } \\
(\%)\end{array}$ & $\begin{array}{l}\text { Geurred. } \\
(\%)\end{array}$ & $\begin{array}{l}\text { Methaanred. } \\
(\%)\end{array}$ & $\begin{array}{l}\text { Fijnstofred. } \\
(\%)\end{array}$ & $\begin{array}{l}\text { Effect op } \\
\text { luchtkwaliteit } \\
\text { in stal }^{1}\end{array}$ & $\begin{array}{l}\text { Toepasbaar } \\
\text { in bestaande } \\
\text { stallen?2,3 }\end{array}$ & Categorieën ${ }^{3}$ \\
\hline \multicolumn{8}{|l|}{ Koelen van mest } \\
\hline Alleen oppervlakte mest & $55 \%$ & $20 \%$ & $20 \%$ & $0 \%$ & + & $\mathrm{Ja}^{6}$ & alle \\
\hline Volledige mest & $55 \%$ & $30 \%$ & $50 \%$ & $0 \%$ & + & $\mathrm{Ja}^{6}$ & alle \\
\hline \multicolumn{8}{|l|}{ Oppervlaktebehandeling mest } \\
\hline Olielaag & $55 \%$ & $50 \%$ & $0 \%$ & $0 \%$ & ++ & $\mathrm{Ja}$ & alle \\
\hline Oppervlaktebeluchting mest & $50 \%$ & $50 \%$ & $50 \%$ & $0 \%$ & ++ & $\mathrm{Ja}^{8}$ & alle \\
\hline \multicolumn{8}{|l|}{ Beluchting mest } \\
\hline Bellenbeluchting mest & $40 \%$ & $20 \%$ & $20 \%$ & $0 \%$ & + & $\mathrm{Ja}^{9}$ & alle \\
\hline \multicolumn{8}{|l|}{ Voermaatregelen } \\
\hline Laag eiwitgehalte; optimaal aminozurenpatroon & $25 \%$ & $30 \%$ & $0 \%$ & $0 \%$ & + & $\mathrm{Ja}$ & alle \\
\hline Verzurende voeders; benzoëzuur & $15 \%$ & $0 \%$ & $0 \%$ & $0 \%$ & + & $\mathrm{Ja}^{12}$ & alle \\
\hline $\begin{array}{l}\text { Zeer goed verteerbare voeders met laag eiwitgehalte en optimaal } \\
\text { aminozuren patroon }\end{array}$ & $25 \%$ & $40 \%$ & $50 \%$ & $0 \%$ & + & Ja & alle \\
\hline Eigen voer met bijproducten & $0 \%$ & $0 \%$ & $0 \%$ & $0 \%$ & $+/-$ & Nee & alle \\
\hline \multicolumn{8}{|l|}{ Verdunnen en koelen van mest } \\
\hline $\begin{array}{l}\text { Opvang mest in water i.c.m. koeling en mestscheiding (dunne } \\
\text { fractie eigen grond of zuiveren en hergebruiken) }\end{array}$ & $60 \%$ & $50 \%$ & $50 \%$ & $0 \%$ & ++ & Ja & alle \\
\hline \multicolumn{8}{|l|}{ Varkenstoilet } \\
\hline Varkenstoilet met toilettraining & $80 \%$ & $80 \%$ & $90 \%$ & $50 \%$ & +++ & Ren. & alle \\
\hline \multicolumn{8}{|l|}{ Schone vloeren } \\
\hline Coaten vloeren en wanden & $5 \%$ & $5 \%$ & $0 \%$ & $5 \%$ & + & $\mathrm{Ja}$ & alle \\
\hline $\begin{array}{l}\text { Goed doorlatende metalen roosters (driekant, met/zonder } \\
\text { mestspleet) }\end{array}$ & $20 \%$ & $0 \%$ & $0 \%$ & $20 \%$ & + & $\mathrm{Ja}^{6}$ & alle ${ }^{13}$ \\
\hline Goede klimatisering en hokinrichting & $20 \%$ & $0 \%$ & $0 \%$ & $20 \%$ & + & Ja & alle \\
\hline Watersproeien op roostervloer tijdens activiteitperioden & $20 \%$ & $10 \%$ & $0 \%$ & $35 \%$ & ++ & $\mathrm{Ja}$ & $V, B, D$ \\
\hline \multicolumn{8}{|l|}{ Strostal } \\
\hline Rondloopstal met voerstation en strobed voor drachtige zeugen & $40 \%$ & $0 \%$ & $0 \%$ & $0 \%$ & + & Nee & $\mathrm{D}$ \\
\hline \multicolumn{8}{|l|}{ Specifieke stofreductie methoden } \\
\hline Olienippel & $0 \%$ & $0 \%$ & $0 \%$ & $65 \%$ & ++ & ja & $V, B, D$ \\
\hline
\end{tabular}




\begin{tabular}{|c|c|c|c|c|c|c|c|}
\hline Brongerichte maatregel & $\begin{array}{l}\text { NH3-red. } \\
(\%)\end{array}$ & $\begin{array}{l}\text { Geurred. } \\
(\%)\end{array}$ & $\begin{array}{l}\text { Methaanred. } \\
(\%)\end{array}$ & $\begin{array}{l}\text { Fijnstofred. } \\
(\%)\end{array}$ & $\begin{array}{l}\text { Effect op } \\
\text { luchtkwaliteit } \\
\text { in stal }^{1}\end{array}$ & $\begin{array}{l}\text { Toepasbaar } \\
\text { in bestaande } \\
\text { stallen?2,3 }\end{array}$ & Categorieën ${ }^{3}$ \\
\hline Oliefilmsysteem met drukleiding & $0 \%$ & $0 \%$ & $0 \%$ & $55 \%$ & + & $\mathrm{Ja}$ & alle \\
\hline \multicolumn{8}{|c|}{ (Toevoeg)middelen aan voer, mest of sprayen in de lucht } \\
\hline Toevoegmiddelen met werkingsmechanisme & $? \%$ & $? \%$ & $? \%$ & $? \%$ & $+/-$ & $\mathrm{Ja}^{15}$ & alle \\
\hline Toevoegmiddelen zonder werkingsmechanisme & $0 \%$ & $0 \%$ & $0 \%$ & $0 \%$ & 0 & $\mathrm{Ja}^{16}$ & alle \\
\hline
\end{tabular}

\section{Tussenvormen van brongericht}

\section{Onderafzuiging van de stallucht onder de roostervloer i.c.m.}

\section{een luchtwasse}

chemische wasser

$95 \%$

$30 \%$

$0 \%$

$35 \%$

$+++$

Ren. ${ }^{5}$

alle

biologische wasser

$70 \% \quad 45 \%$

$0 \%$

$75 \%$

$+++$

Ren. $^{5}$

alle

gecombineerde wasser

Gedeeltelijk onder de roostervloer (min. ventilatie); gedeeltelijk

$85 \%$

$45 \%$

$0 \%$

$80 \%$

$+++$

Ren. ${ }^{5}$

alle

wassen; 95\% chemische wasser

Gedeeltelijk onder de roostervloer (min. ventilatie); gedeeltelijk

wassen; $70 \%$ biologische wasser

Gedeeltelijk onder de roostervloer (min. ventilatie); gedeeltelik

$65 \%$

$20 \%$

$0 \%$

$20 \%$

$++$

Ren. ${ }^{5}$

alle

wassen; $85 \%$ gecombineerde wasser

$0 \%$

$40 \%$

$++$

Ren. $^{5}$

alle

Gedeeltelijke recirculatie van lucht

Gedeeltelijke recirculatie van lucht met combiwasser $85 \%$

$60 \%$

$30 \%$

$0 \%$

$40 \%$

$++$

Ren. ${ }^{5}$

alle

\section{Luchtreiniging in de stal}

Koude plasmatechnologie

$90 \%$

$50 \%$

$0 \%$

$85 \%$

$++$

$\mathrm{Ja}^{11}$

alle

Hogere minimum ventilatie i.c.m. conditionering inkomende

lucht

Conditionering inkomende lucht met warmtewisselaar en verhoging

$50 \%$

$50 \%$

$50 \%$

$50 \%$

$++$

$++$

$\mathrm{Ja}^{10}$

alle

minimum ventilatie, i.c.m. chemische luchtwasser $95 \%{ }^{14}$ 


\begin{tabular}{|c|c|c|c|c|c|c|c|}
\hline Brongerichte maatregel & $\begin{array}{l}\text { NH3-red. } \\
(\%)\end{array}$ & $\begin{array}{l}\text { Geurred. } \\
(\%)\end{array}$ & $\begin{array}{l}\text { Methaanred. } \\
(\%)\end{array}$ & $\begin{array}{l}\text { Fijnstofred. } \\
(\%)\end{array}$ & $\begin{array}{l}\text { Effect op } \\
\text { luchtkwaliteit } \\
\text { in stal }^{1}\end{array}$ & $\begin{array}{l}\text { Toepasbaar } \\
\text { in bestaande } \\
\text { stallen } ?^{2,3}\end{array}$ & Categorieën ${ }^{3}$ \\
\hline
\end{tabular}

\section{Specifieke stofreductie methoden}

Negatieve luchtionisatie

$0 \%$

$0 \%$

Interne luchtcirculatie met stoffiltratie (air cleaner)

$0 \%$

$50 \%$

$+$

1) 0 = geen effect; $+/-=$ effect onbekend; + = gematigd positief; $++=$ positief; $+++=$ zeer positief

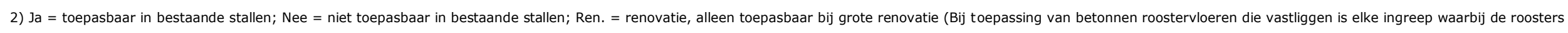
moeten worden verwijderd een grote renovatie.)

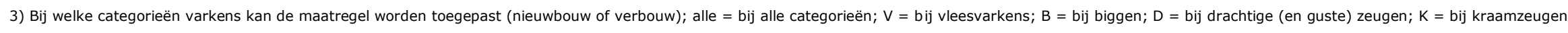

4) Alleen bij bolle vloeren met goed afvoersysteem; bij drachtige zeugen alleen bij bepaalde hokontwerpen mogelijk.

5) Ontwerp erg belangrijk van de onderafzuiging; volledig onder afzuigen moeilijk in bestaande stallen.

6) Ren. bij betonnen roosters die vastliggen.

7) Aanvullend onderzoek nodig ten aanzien van aantasting beton en grote hoeveelheden zwavel in de mest. Deens onderzoek als startpunt gebruiken.

8) Nog slechts in idee-stadium; onderzoek nodig, dus niet voor korte termijn

9) Bij rundvee vallen de uiteindelijke resultaten tegen; nog geen erkenning bij rundvee; onderzoek nodig bij varkens.

10) Nog in onderzoek en ontwikkeling; kan eventueel ook als end of pipe systeem worden toegepast (dan hogere reducties)

11) Bij aanwezigheid centraal aan- en afvoerkanaal van lucht; nog verder onderzoek nodig.

12) $16 \%$ ammoniakreductie bij $1 \%$ toevoeging benzoëzuur aan het voer.

13) Bij drachtige zeugen alleen toepassen op een klein deel van de roostervloer, daar waar naar verwachting veel wordt gemest.

14) Ook combinaties met andere luchtwassers zijn mogelijk (reducties gelijk aan die opgenomen in de Rav-lijst).

15) Het effect en toepasbaarheid is afhankelijk van het soort middel. Het mag de veiligheid van dier, mens of voedsel niet in gevaar brengen.

16) Van deze middelen wordt weinig verwacht. Eventueel onderzoek zal zich moeten richten op het werkingsmechanisme en potentiele effecten. Bij voorkeur wordt dit op het lab of op kleine schaal uitgetest. 

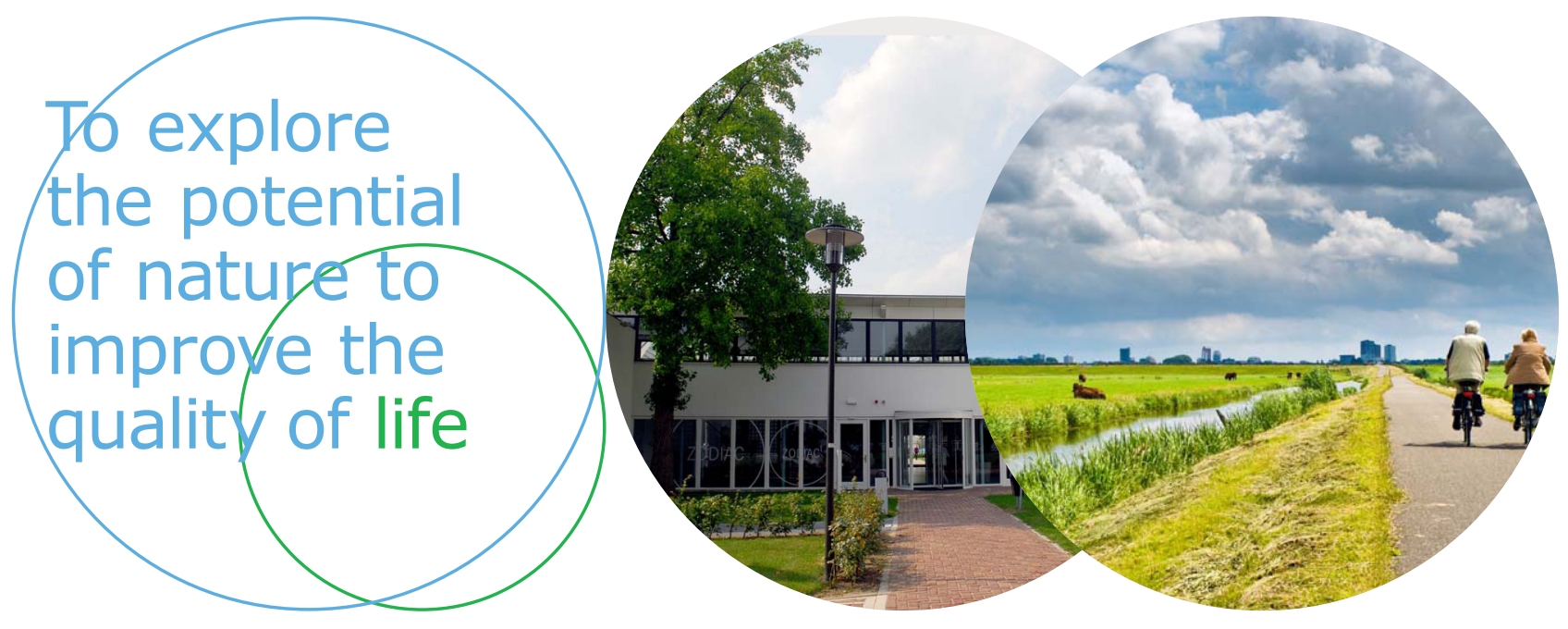

Wageningen Livestock Research Postbus 338

Wageningen Livestock Research ontwikkelt kennis voor een zorgvuldige en $6700 \mathrm{AH}$ Wageningen

T 0317483953

renderende veehouderij, vertaalt deze naar praktijkgerichte oplossingen en innovaties, en zorgt voor doorstroming van deze kennis. Onze wetenschappelijke E info.livestockresearch@wur.nl www.wur.nl/ livestock-research kennis op het gebied van veehouderijsystemen en van voeding, genetica, welzijn en milieu-impact van landbouwhuisdieren integreren we, samen met onze klanten, tot veehouderijconcepten voor de $21 \mathrm{e}$ eeuw.

De missie van Wageningen University \& Research is 'To explore the potential of nature to improve the quality of life'. Binnen Wageningen University \& Research bundelen 9 gespecialiseerde onderzoeksinstituten van Stichting Wageningen Research en Wageningen University hun krachten om bij te dragen aan de oplossing van belangrijke vragen in het domein van gezonde voeding en leefomgeving. Met ongeveer 30 vestigingen, 6.500 medewerkers en 10.000 studenten behoort Wageningen University \& Research wereldwijd tot de aansprekende kennisinstellingen binnen haar domein. De integrale benadering van de vraagstukken en de samenwerking tussen verschillende disciplines vormen het hart van de unieke Wageningen aanpak. 